\title{
Ciências para as crianças: a Transposição Didática na formação inicial em Pedagogia como processo criativo de (trans)formação
}

\author{
Giséli Duarte Bastos*, Rosemar de Fátima Vestena ${ }^{\star \star}$, Lenira Maria Nunes Sepel ${ }^{\star \star \star}$
}

\section{Resumo}

Tendo em vista a curiosidade natural das crianças em questionar, testar e criar, torna-se latente que o ensino das Ciências da Natureza para os primeiros anos escolares valorize e estimule tais características, aliando-as aos aspectos da própria Ciência e de seu desenvolvimento. Para tanto, emerge a necessidade de investir-se em uma formação inicial de Pedagogos voltada a esse fim. A partir de uma disciplina sobre o Ensino de Ciências, ofertada a estudantes de Licenciatura em Pedagogia, de uma Instituição Pública de Ensino Superior, da região central do Rio Grande do Sul, Brasil, nos propomos a analisar a produção de planejamentos de atividades voltadas às Ciências da Natureza para os anos iniciais, elaborados pelas alunas ao final da disciplina. Objetivamos investigar como se deu o processo de Transposição Didática (TD) dos conhecimentos. Para tanto, à luz da Análise de Conteúdo, elegemos quatro elementos organizativos da análise, considerando a influência: das crianças ao perguntarem, das políticas públicas, da formação inicial e das concepções pessoais das estudantes. A análise dos dados demonstrou o processo de TD como um produto inédito para cada futura docente. As estudantes elaboraram seus planejamentos explorando aspectos epistemológicos, pedagógicos e psicológicos das Ciências, valorizando as características infantis aliadas ao fazer científico. Nossos resultados reiteram o quanto um processo formativo inicial pode suscitar fagulha de (trans)formação nos sujeitos que os compartilham, reforçando a responsabilidade dos Cursos de Pedagogia em oferecerem oportunidades de formação que valorizem ideias e estimulem a criação e a autonomia em Ciências.

Palavras-chave: Formação inicial, Pedagogia, Anos Iniciais, Ensino de Ciências, Transposição Didática.

- Doutora em Educação em Ciências, Técnica em Assuntos Educacionais na Universidade Federal de Santa Maria, Santa Maria, Rio Grande do Sul, Brasil - giseli.bastos@ufsm.br.

" Doutora em Educação em Ciências, Professora na Universidade Franciscana, Santa Maria, Rio Grande do Sul, Brasil - rosemarvestena@gmail.com.

*** Doutora em Educação em Ciências, Professora na Universidade Federal de Santa Maria, Santa Maria, Rio Grande do Sul, Brasil - lenirasepel@gmail.com.

Recebido: 05/03/2020 - Aceito em: 23/11/2020

https://doi.org/10.5335/rbecm.v4i1.10956

http://creativecommons.org/licenses/by-nc-nd/4.0 


\section{Introdução}

Durante muitos anos, as crianças foram consideradas como adultos em miniatura, atualmente, devido à psicologia cognitiva e à psicologia genética, sabe-se que possuem uma maneira particular de significar o mundo que as cerca (MALAFAIA; RODRIGUES, 2008). Quando alguém acredita que as crianças não são capazes de aprender Ciências, portanto, demonstra uma incompreensão das características psicológicas do pensamento infantil e também uma desvalorização da criança enquanto sujeito social (MALAFAIA; RODRIGUES, 2008).

De um modo geral, crianças são naturalmente curiosas, possuem motivação aguçada para descobrir algo novo para elas, questionar, testar e criar (LIMA; MAUÉS, 2006). Da mesma forma, o fazer científico é permeado por perguntas e dúvidas, exige criatividade, discussão coletiva, formulação de hipóteses e experimentações variadas (PIRES; SAUCEDO; MALACARNE, 2017). Nesse sentido, torna-se latente que o Ensino de Ciências para os primeiros anos da escolaridade seja desenvolvido de tal forma a estimular ainda mais essas características infantis, aliando-as às características da própria Ciência.

Concordamos com os autores que defendem o Ensino de Ciências construído por meio da promoção da Alfabetização Científica (AC), considerando esse processo como uma "enculturação", por meio da qual os alunos são inseridos em mais uma cultura: a científica (LORENZETTI; DELIZOICOV, 2001; BRANDI; GURGEL, 2002; CACHAPUZ et al., 2005; SASSERON; CARVALHO, 2011). A versão aprovada em 2017 da Base Nacional Comum Curricular (BNCC), documento de caráter normativo que se coloca como uma exigência ao sistema educacional brasileiro, apresenta a área das Ciências da Natureza aos anos iniciais do ensino fundamental como responsável pelo acesso à diversidade de conhecimentos científicos produzidos ao longo da história, bem como pelo desenvolvimento da familiaridade com processos, práticas e procedimentos de investigação científica, trabalhada na perspectiva da AC (BRASIL, 2017). O documento propõe que a organização das situações de aprendizagem parta de questões desafiadoras, estimulando o interesse e a curiosidade científica dos alunos, possibilitando a definição de problemas, levantamentos, análise e representações de resultados, além da comunicação de conclusões e proposição de intervenções (BRASIL, 2017). 
Diante do desafio apresentado, diferentes autores (MALDANER; ZANON; AUTH, 2006; LIMA; MAUÉS, 2006; OVIGLI; BERTUCCI, 2009; DELIZOICOV; SLONGO, 2011) apontam um foco sobre a formação inicial dos professores habilitados a ensinar Ciências nos anos iniciais do ensino fundamental: os pedagogos. Comprometem, assim, as Instituições de Ensino Superior com a qualidade do processo formativo desses professores.

A partir de uma disciplina voltada ao Ensino de Ciências visando à AC, oferecida a estudantes de Licenciatura em Pedagogia, nos propomos a analisar a produção dos planejamentos de atividades voltadas às Ciências da Natureza para os anos iniciais, elaborados pelas alunas ao final da disciplina. Objetivamos investigar como se deu o processo de Transposição Didática (TD) dos conhecimentos a partir das influências da formação vivenciada pelas estudantes ao longo da disciplina. A TD pode ser entendida como um processo de didatização do saber científico para se transformar em noções suscetíveis de aprendizagem e todo professor, de alguma forma, realiza no esforço de possibilitar ao aluno a apropriação e a reconstrução de determinado saber (BOSCH; GASCÓN, 2006).

Questionamo-nos, portanto: quais fatores se mostram influenciadores e como se mostram esses fatores no processo de Transposição Didática de conhecimentos das Ciências da Natureza, realizado no contexto da formação inicial em Pedagogia, a partir de uma disciplina voltada ao Ensino de Ciências na perspectiva da Alfabetização Científica?

O trabalho está organizado a partir da apresentação de uma breve revisão de literatura acerca do Ensino de Ciências na formação inicial em Pedagogia e o processo de TD, seguido das construções metodológicas que delinearam a pesquisa, contendo explicações sobre a disciplina desenvolvida e sobre a análise dos dados. Após, encontram-se os resultados e as discussões divididas em quatro elementos organizativos da análise, considerando a influência: das crianças ao perguntarem, das políticas públicas, da formação inicial e das concepções pessoais das estudantes ao planejarem suas atividades. Por fim, algumas considerações finais são apresentadas.

REVISÃO DE LITERATURA

A formação inicial de Pedagogos e o Ensino de Ciências

A formação de professores não pode ser reduzida a uma mera aquisição de informação nova ou ao desenvolvimento de alguma habilidade: formar-se é autoconstruir-se (ZABALZA, 2004). A qualidade dessa autoconstrução, no entanto, vem 
condicionada à intervenção formativa e também à forma como esse processo ocorre (ZABALZA, 2004).

Diante da formação inicial de Pedagogos, a qual se realiza por meio do curso de Licenciatura em Pedagogia (BRASIL, 2006), estabelece-se um cenário complexo. Esses profissionais, além de outras habilitações, serão os responsáveis pelo processo de ensino-aprendizagem de diferentes áreas nos anos iniciais da escolaridade, sendo denominados, muitas vezes, de professores polivalentes. De acordo com Pimenta et al. (2017) a denominação polivalente marca a atuação desse profissional desde a então escola normal de ensino médio, nos finais do século XIX, cuja finalidade era formar o professor para ensinar as disciplinas de Língua Portuguesa (alfabetização), Matemática, História, Geografia e Ciências. As Diretrizes para o curso não apresentam mais essa denominação, mas a finalidade permanece sendo a de formar professores para lecionar as disciplinas básicas nos anos iniciais (PIMENTA et al., 2017).

Tendo em vista essa conjuntura, pesquisadores vêm questionando os currículos dos cursos de Pedagogia no Brasil acerca das condições fornecidas para a formação profissional nas disciplinas específicas para uma atuação "polivalente" (GATTI; NUNES, 2009; GATTI; BARRETO, 2009; LIBÂNEO, 2010, 2012b; PIMENTA et al., 2017; MARAFELLI; RODRIGUES; BRANDÃO, 2017).

Gatti e Nunes (2009) realizaram um estudo sobre as proposições das disciplinas e conteúdos dos currículos dos cursos presenciais de Licenciatura no Brasil, entre eles, a Pedagogia. A análise das ementas do Curso de Pedagogia, em relação à formação para atuação nas disciplinas específicas, evidenciou uma predominância de aspectos teóricos, contemplando pouco as possibilidades de práticas educacionais associadas a esses aspectos (GATTI; NUNES, 2009).

Pimenta et al. (2017) analisaram as ementas dos Curso de Licenciatura em Pedagogia do Estado de São Paulo concluindo que a formação dos Pedagogos nesse contexto, em sua maioria, se mostra frágil, superficial, generalizante, sem foco na formação de professores, fragmentada e dispersiva. Libâneo (2012b) apresenta a existência, na maioria dos currículos de Pedagogia no Brasil, de uma acentuada separação conteúdo-forma caracterizada pela predominância da forma (do "metodológico”) com menor preocupação com os conhecimentos específicos que serão ensinados às crianças. Para o autor, os currículos dos cursos de Licenciatura em Pedagogia refletem uma tradição de formar professores mais para cuidar do que 
para ensinar. Marafelli, Rodrigues e Brandão (2017) a partir da análise de diversas pesquisas sobre o curso de Pedagogia, discorrem que a resposta às críticas vem repercutindo nas Instituições de Ensino Superior, na maioria das vezes, em aumento da carga horária dos estágios, sem a ampliação necessária ao aprendizado prático da docência sob supervisão institucional.

Considerando a complexidade de uma formação para o ensino de diferentes áreas, Libâneo (2012a) defende que a integração entre didática e epistemologia das disciplinas faz-se necessária e a formação de professores passa, necessariamente, pelo estudo das bases epistemológicas das disciplinas ensinadas. Desse modo, o ensino de conteúdos específicos requer métodos e organização particularizados, do mesmo modo que não é possível ensinar conteúdos "em si", separados dos seus procedimentos lógicos e investigativos.

De acordo com Astolfi e Develay (2001), cada sugestão didática para as Ciências depende de reflexões epistemológicas, pedagógicas e psicológicas, imbricadas entre si, abrangendo com maior proximidade a complexidade do ensino da área e da educação como um todo. Nesse contexto, a formação docente precisa ser trabalhada em direção à superação do senso comum pedagógico, o qual faz acreditar que a apropriação de conhecimentos ocorre pela mera transmissão mecânica de informações (DELIZOICOV; ANGOTTI; PERNAMBUCO, 2002). Pizarro, Barros e Lopes-Junior (2016) colocam como ingênua a crença de que ensinar Ciências nos anos iniciais resume-se a ensinar conceitos. Quando escolarizada, as Ciências precisam fazer sentido para as crianças, ajudando-as a compreender o mundo que as cerca (OVIGLI; BERTUCCI, 2009).

O conhecimento de epistemologia torna os professores capazes de melhor compreender que Ciência estão transpondo para o ensino, auxiliando-os na melhoria de suas próprias concepções de Ciência e na fundamentação da sua ação pedagógico-didática (PRAIA; CACHAPUZ; GIL-PÉREZ, 2002). Pedagogicamente, Santos (2016) destaca uma diversidade metodológica possível para as Ciências, a partir de uma formação inicial que visa clarificar epistemologicamente a área, tais como: aulas de campo, visitas a museus, observação, elaboração de hipóteses e experimentação, para que haja a organização de estratégias que sejam propícias à ação dos alunos no processo de ensino e aprendizagem, entre outros.

A partir de reflexões epistemológicas e pedagógicas, temos também a importância da reflexão psicológica que dá conta de compreender a criança como um 
sujeito coletivo, cuja constituição é caracterizada pelas esferas simbólica, social e produtiva (DELIZOICOV; ANGOTTI; PERNAMBUCO, 2002). Para os autores, isso implica considerar que cada estudante interage e estabelece relações com o meio físico e social, apropriando-se de padrões de comportamento e de linguagem para abordagem do objeto do conhecimento.

Acreditamos que a formação inicial dos Pedagogos para o ensino de Ciências na perspectiva da AC é capaz de fornecer subsídios para que os estudantes realizem reflexões epistemológicas, pedagógicas e psicológicas próprias das Ciências. Para tanto, ao se didatizar os conhecimentos científicos, num complexo caminho percorrido entre o contexto de produção das teorias e modelos até sua inclusão no currículo escolar, processo denominado de Transposição Didática, é necessário discernir a diferenciação fundamental entre objetos do conhecimento e conhecimentos produzidos por esses objetos (DELIZOICOV; ANGOTTI; PERNAMBUCO, 2002).

Assim, destacamos a importância do processo de TD realizado pelos futuros docentes em contexto de formação inicial, mesmo quando não postas em ação de sala de aula. A próxima seção apresenta, brevemente, nossa concepção acerca desse processo.

\section{A Transposição Didática como processo de criação}

Há uma especificidade no conhecimento escolar e no discurso pedagógico os quais, ao serem curricularizados, sofrem um processo de tradução para fins de ensino chamado de Transposição Didática (TD) (LOPES; MACEDO, 2011).

O modelo de TD foi proposto inicialmente pelo sociólogo Verret em 1975, e depois desenvolvido por Chevallard em 1985. Chevallard analisou, no domínio da Matemática, a passagem do "conhecimento científico" de referência, para o "conhecimento a ensinar" e deste para o "conhecimento ensinado" (CHEVALLARD, 1991). Este modelo foi, numa segunda fase, aplicado a outras áreas disciplinares, como as Ciências (ASTOLFI; DEVELAY, 2001).

De acordo com Bosch e Gascón (2006), o processo de TD começa longe da escola e da sala de aula, quando uma diversidade de agentes políticos, acadêmicos, membros do sistema educacional, a chamada "noosfera", seleciona os corpos de conhecimento a serem transmitidos e os reconstrói para torná-los “ensináveis”. Essa transformação, centrada nos processos de seleção dos conteúdos curriculares a partir do conheci- 
mento científico de referência, dando origem aos currículos e programas escolares, chamamos de Transposição Didática Externa. Já a Transposição Didática Interna preocupa-se com a maneira como os conteúdos são transpostos em contextos de aprendizagem formais e não formais (BOSCH; GASCÓN, 2006). Assim, na sala de aula, a partir das ações do professor, o saber aparece na forma de saber ensinado, o qual, na interação com os alunos, será transformado em saber aprendido.

Lopes e Macedo (2011) destacam que uma das principais contribuições da teoria da TD diz respeito ao caráter produtivo do processo pedagógico. Para as autoras, a TD apresenta argumentos que sustentam a tese de que a escola não é apenas um receptáculo de saberes produzidos em outras instâncias, mas participa de uma esfera mais ampla que reinterpreta diferentes saberes sociais para fins de ensino. Dessa forma, cria-se uma configuração epistemológica própria para o conhecimento escolar e uma dimensão sociológica para o discurso pedagógico, favorecendo a leitura de que a escola não deve ser analisada de forma submissa a do conhecimento científico (LOPES; MACEDO, 2011).

Banegas (2014) defende a TD a partir de uma perspectiva sociocultural, substituindo a ideia de uma transmissão monolítica para uma que ouça as vozes dos diferentes agentes, principalmente, os envolvidos na TD Interna: professor e estudante. $\mathrm{O}$ autor apresenta outros pesquisadores sustentando a tese de que os aprendizes exercem influência no currículo, na elaboração das aulas e na forma como os conteúdos são ensinados, por meio de uma negociação permanente que desconstrói qualquer possibilidade de linearidade na TD. Dessa forma, cada professor e cada turma de estudantes negociam a transposição dos conteúdos de diferentes maneiras, dependentes das práticas sociais de referência, bem como dos valores pessoais desses sujeitos (BENEGAS, 2014).

\section{Construções metodológicas}

A pesquisa de natureza empírica, de abordagem qualitativa e de cunho documental foi realizada com oito estudantes de Pedagogia, regularmente matriculadas em uma disciplina optativa, em uma Instituição Pública de Ensino Superior, localizada na região central do Rio Grande do Sul, Brasil. Por se tratar de uma disciplina optativa, as estudantes encontravam-se em diferentes estágios do Curso. A pesquisa documental, segundo Oliveira (2007), caracteriza-se pela busca de informações em documentos que 
não receberam nenhum tratamento científico. Documento pode ser entendido de forma ampla, incluindo materiais escritos (jornais, revistas, diários, cartas, relatórios, entre outros), estatísticas e elementos icônicos (imagens, grafismos, desenhos, filmes, entre outros) (GODOY, 1995). Para a autora, esse tipo de pesquisa permite que a imaginação e a criatividade levem os investigadores a proporem trabalhos que explorem novos enfoques, revestindo a pesquisa de um caráter inovador e trazendo contribuições importantes no estudo de alguns temas.

Assim, pesquisa reúne a análise dos planejamentos de aulas construídos pelas estudantes da disciplina entregues e apresentados à turma na última aula do semestre. A proposta da realização dos planejamentos era de conhecimento das estudantes desde o início da disciplina, bem como a possibilidade de tirar dúvidas junto à professora regente/pesquisadora acerca da elaboração deles. A proposta era que, a partir de questionamentos infantis ou típicos de crianças, as estudantes desenvolvessem atividades para respondê-los.

\section{A disciplina}

Desenvolvida entre os meses de agosto e dezembro de 2017, a disciplina contou com uma carga horária de 30 horas, com aulas semanais de 2 horas. O Quadro 1 apresenta os principais tópicos e atividades desenvolvidos ao longo das 15 aulas.

Quadro 1: Atividades desenvolvidas e materiais didáticos utilizados ao longo das 15 aulas da disciplina

(continua...)

\begin{tabular}{|l|l|l|}
\hline Aula & \multicolumn{1}{|c|}{ Atividades desenvolvidas } & Materiais didáticos e recursos utilizados \\
\hline 1 & $\begin{array}{l}\text { Apresentação geral da disciplina, entrega dos Diários e expli- } \\
\text { cação da atividade final. }\end{array}$ & $\begin{array}{l}\text { Diário de bordo no qual as estudantes } \\
\text { registram sua formação ao longo da } \\
\text { disciplina. }\end{array}$ \\
\hline 2 & $\begin{array}{l}\text { Atividade sobre História e Filosofia da Ciência (HFC): "Um mu- } \\
\text { seu na sala de aula". Linha do tempo sobre o conhecimento } \\
\text { acerca da reprodução humana. }\end{array}$ & $\begin{array}{l}\text { "Diário de Viagem"; } \\
\text { Imagens impressas; } \\
\text { Microscópio; } \\
\text { Globo terrestre. }\end{array}$ \\
\hline 3 & $\begin{array}{l}\text { Aula teórica - Sistematização conhecimento sobre HFC - Apre- } \\
\text { sentando as visões distorcidas da Ciência } \\
\text { Discussão e questão reflexiva sobre as crianças e o fazer cien- } \\
\text { tífico. } \\
\text { Atividade para a casa: recomendação da leitura do livro "A re- } \\
\text { forma da Natureza" de Monteiro Lobato. }\end{array}$ & $\begin{array}{l}\text { Powerpoint; } \\
\text { Questão reflexiva. }\end{array}$ \\
\hline 4 & $\begin{array}{l}\text { Aplicação do conhecimento HFC: análise coletiva do livro "A } \\
\text { reforma da Natureza" de Monteiro Lobato } \\
\text { Entrega da análise individual. }\end{array}$ & $\begin{array}{l}\text { Livro "A reforma da natureza" de Mon- } \\
\text { teiro Lobato. }\end{array}$ \\
\hline
\end{tabular}




\begin{tabular}{|c|c|c|}
\hline 5 & $\begin{array}{l}\text { Atividade investigativa (lúdica) sobre fotossíntese: "As plantas } \\
\text { produzem gases?" }\end{array}$ & $\begin{array}{l}\text { Tubos de ensaio; } \\
\text { Luminária; } \\
\text { Planta aquática Elodea; } \\
\text { "Roteiros" para anotações e desenhos. }\end{array}$ \\
\hline 6 & $\begin{array}{l}\text { Aula teórica - Fundamentos da investigação em sala de aula: } \\
\text { formulação de perguntas, as hipóteses na Ciência e no Ensino } \\
\text { de Ciências. Estímulo à criatividade infantil. } \\
\text { Discussão coletiva. }\end{array}$ & Powerpoint. \\
\hline 7 & $\begin{array}{l}\text { Construção do microscópio de garrafa pet } \\
\text { Atividade para casa: Observar e desenhar alguma estrutura } \\
\text { utilizando o microscópio de garrafa pet. }\end{array}$ & $\begin{array}{l}\text { Garrafa pet; } \\
\text { Lentes de aumento; } \\
\text { Cola durepox. }\end{array}$ \\
\hline 8 & $\begin{array}{l}\text { Laboratório: As células estão derretendo? Aula prática com in- } \\
\text { dução de plasmólise em célula de cebola roxa, com estímulo à } \\
\text { formulação de hipóteses e explicações. } \\
\text { Entrega atividade de observação com microscópio de garrafa } \\
\text { pet. }\end{array}$ & $\begin{array}{l}\text { Microscópio óptico; } \\
\text { cebola roxa; } \\
\text { lâmina; } \\
\text { lamínula; } \\
\text { pinça; } \\
\text { conta-gotas, etc. }\end{array}$ \\
\hline 9 & $\begin{array}{l}\text { Laboratório: Por que as folhas são verdes? Extração de pig- } \\
\text { mentos vegetais e continuação da teoria sobre fotossíntese. }\end{array}$ & $\begin{array}{l}\text { Microscópio; } \\
\text { Folhas de couve, pistilo, almofariz; } \\
\text { Solvente; } \\
\text { Mapa conceitual. }\end{array}$ \\
\hline 10 & $\begin{array}{l}\text { Campo - Quantos seres cabem em um pequeno espaço na gra- } \\
\text { ma? Observações cuidadosas de perto e de longe da natureza. }\end{array}$ & $\begin{array}{l}\text { Lupa (observação de perto), binóculos } \\
\text { (observação de longe), palitos e barban- } \\
\text { te, folhas para desenhos e anotações. }\end{array}$ \\
\hline 11 & Campo - Atividade dinâmica "Explorando o Campus". & $\begin{array}{l}\text { Luvas, sacos plásticos, livro didático, } \\
\text { guia de atividades do "explorador". }\end{array}$ \\
\hline 12 & $\begin{array}{l}\text { Atividade reflexiva sobre as aulas de Campo: atividade escrita } \\
\text { de auto-avaliação, seguida de discussão coletiva a partir de } \\
\text { esquema relacional. }\end{array}$ & $\begin{array}{l}\text { Esquema relacional em papel pardo; } \\
\text { Auto-avaliação. }\end{array}$ \\
\hline 13 & $\begin{array}{l}\text { Atividade para as crianças: aula teórica com apresentação das } \\
\text { Ciências da Natureza na Base Nacional Comum Curricular } \\
\text { para embasar a escolha da temática da atividade final. }\end{array}$ & $\begin{array}{l}\text { Powerpoint; } \\
\text { Discussão coletiva. }\end{array}$ \\
\hline 14 & $\begin{array}{l}\text { Atividade para as crianças: discussão dos projetos e temas es- } \\
\text { colhidos para a atividade final, orientação individual, entrega } \\
\text { dos Diários. As dúvidas são discutidas individualmente. }\end{array}$ & Aula de orientação aos planejamentos. \\
\hline 15 & $\begin{array}{l}\text { Apresentação individual das atividades finais e entrega do pro- } \\
\text { jeto escrito; } \\
\text { Diários são devolvidos às estudantes; } \\
\text { Confraternização. }\end{array}$ & $\begin{array}{l}\text { Uso de recurso áudio-visual pelas es- } \\
\text { tudantes para apresentação. }\end{array}$ \\
\hline
\end{tabular}

Fonte: As autoras (2017).

A coleta de dados se deu a partir dos planejamentos escritos entregues à professora/pesquisadora e da apresentação realizada pelas estudantes no último dia de aula. Para análise dos dados, utilizamos a Análise de Conteúdo a qual proporciona o levantamento de indicadores que permitem a realização de inferência de conhecimentos (BARDIN, 2011), além do acesso ao repertório semântico ou sintático de determinado grupo social ou profissional (OLIVEIRA, 2008). Assim, a Análise 
de Conteúdo emerge como técnica que se propõe à apreensão de uma realidade explícita, mas também de uma realidade invisível, que pode se manifestar apenas nas "entrelinhas" do texto (CAVALCANTE; CALIXTO; PINHEIRO, 2014). Bardin (2011) define três etapas para o processo de análise de conteúdo: i) pré-análise; ii) exploração do material e iii) tratamento dos resultados, inferência e interpretação.

A pré-análise (i) consiste na fase em que se organiza o material a ser analisado com o objetivo de torná-lo operacional, sistematizando as ideias iniciais e a exploração do material (ii) abarca uma identificação de unidades de registro, construindo uma categorização base. Dessa forma, durante as etapas (i) e (ii) da Análise de Conteúdo, analisamos os planejamentos utilizando quatro categorias - base (a priori) para organização dos demais dados. Acreditávamos que essas categorias estariam imbricadas no processo de TD realizadas pelas estudantes. A primeira delas denominamos de "vozes das crianças", representada pelos questionamentos iniciais que deram origem aos planejamentos. A segunda identificamos como "respaldo das políticas públicas" uma vez que os tópicos elencados na condução dos planejamentos estão presentes na BNCC. A terceira, denominada "formação inicial", representa as construções teóricas realizadas à luz da formação no curso de Pedagogia e na disciplina ministrada pela professora/pesquisadora. A quarta, “concepções pessoais”, retrata os valores e práticas de referências das estudantes passíveis de influência nos planejamentos. Na etapa iii, tentamos encontrar elementos que pudessem demonstrar a influência e a forma como estavam imbricados esses elementos na TD realizada pelas estudantes às crianças.

\section{Resultados E Discussão}

Para elucidação da produção das estudantes, construímos o Quadro 2, identificando-as por letras. 
Quadro 2: Resumo das atividades elaboradas pelas estudantes em seus planejamentos

\begin{tabular}{|c|c|c|c|c|}
\hline Estudante & $\begin{array}{c}\text { Questionamento } \\
\text { infantil }\end{array}$ & $\begin{array}{l}\text { Origem da } \\
\text { pergunta }\end{array}$ & $\begin{array}{l}\text { O que será } \\
\text { trabalhado? }\end{array}$ & Resumo do planejamento \\
\hline$A$ & $\begin{array}{l}\text { "A água que } \\
\text { cai da chuva é } \\
\text { a mesma que } \\
\text { bebemos?" }\end{array}$ & $\begin{array}{lr}\text { Uma aluna } & \text { da } \\
\text { estudante } & \text { a } \\
\text { questionou } & \text { em } \\
\text { aula (estágio). }\end{array}$ & $\begin{array}{l}\text { Ciclo da água, im- } \\
\text { portância da água, } \\
\text { evitar desperdício. }\end{array}$ & $\begin{array}{l}4 \text { dias de aula: Criação de hipóteses pelas } \\
\text { crianças. Pesquisa teórica realizada pelas } \\
\text { crianças utilizando computador. Construção de } \\
\text { filtro de água da chuva caseiro pelas crianças. } \\
\text { Aula de laboratório com visualização de amos- } \\
\text { tras de água. Visita técnica a uma estação de } \\
\text { tratamento de água. }\end{array}$ \\
\hline$A C$ & $\begin{array}{l}\text { "O que acon- } \\
\text { teceria se as } \\
\text { abelhas desa- } \\
\text { parecessem?" }\end{array}$ & $\begin{array}{l}\text { Curiosidade pró- } \\
\text { pria da estudante. }\end{array}$ & $\begin{array}{ll}\text { Importância } & \text { da } \\
\text { polinização e } & \text { da } \\
\text { preservação } & \text { do } \\
\text { meio-ambiente. }\end{array}$ & $\begin{array}{l}5 \text { dias de aula. Estímulo à elaboração de hipó- } \\
\text { teses pelas crianças. Leituras de textos pelas } \\
\text { crianças. Aprsentação do filme Bee Movie. Te- } \\
\text { atro elaborado e estrelado pelas crianças para } \\
\text { representar as abelhas polinizando e as con- } \\
\text { sequências do desaparecimento das abelhas. }\end{array}$ \\
\hline $\mathrm{C}$ & $\begin{array}{l}\text { "Alguns ali- } \\
\text { mentos podem } \\
\text { fazer mal à } \\
\text { saúde?" }\end{array}$ & $\begin{array}{l}\text { Um aluno da es- } \\
\text { tudante a ques- } \\
\text { tionou em aula } \\
\text { (estágio). }\end{array}$ & $\begin{array}{l}\text { Nutrientes: Com- } \\
\text { ponentes dos ali- } \\
\text { mentos, hábitos } \\
\text { alimentares, grá- } \\
\text { ficos. }\end{array}$ & $\begin{array}{l}4 \text { dias de aula: Análise de rótulos de alimen- } \\
\text { tos trazidos de casa pelas crianças. Pesquisa, } \\
\text { compilação de dados e construção de gráficos } \\
\text { e comunicação dos resultados dos hábitos ali- } \\
\text { mentares dos familiares em aula. Lanche sau- } \\
\text { dável coletivo entre os colegas. }\end{array}$ \\
\hline CJ & $\begin{array}{l}\text { "Como nascem } \\
\text { as borbole- } \\
\text { tas?" }\end{array}$ & $\begin{array}{l}\text { Curiosidade do } \\
\text { filho da estudante. }\end{array}$ & $\begin{array}{l}\text { Ciclo de vida da } \\
\text { borboleta. }\end{array}$ & $\begin{array}{l}3 \text { dias de aula: Aula de campo. Utilização de } \\
\text { história infantil e de materiais lúdicos (quebra- } \\
\text {-cabeças e televisão de papelão). Propor que } \\
\text { as crianças desenhem. }\end{array}$ \\
\hline I & $\begin{array}{l}\text { "Se gelo tam- } \\
\text { bém é de água } \\
\text { como ele boia } \\
\text { na água?" }\end{array}$ & $\begin{array}{l}\text { Curiosidade apre- } \\
\text { sentada pelo ir- } \\
\text { mão da estudante. }\end{array}$ & $\begin{array}{l}\text { Densidade, empu- } \\
\text { xo, propriedades } \\
\text { físicas dos mate- } \\
\text { riais, solubilidade, } \\
\text { mudanças de es- } \\
\text { tado físico da água. }\end{array}$ & $\begin{array}{l}2 \text { dias de aula: Criação de hipóteses pelas } \\
\text { crianças. Experiências utilizando água, gelo, } \\
\text { tinta, óleo. Utilização de História da Ciência. }\end{array}$ \\
\hline L & $\begin{array}{l}\text { "Será que pe- } \\
\text { dra é um ser } \\
\text { vivo?" }\end{array}$ & $\begin{array}{l}\text { Curiosidade apre- } \\
\text { sentada pela filha } \\
\text { da estudante. }\end{array}$ & $\begin{array}{l}\text { Conceito de seres } \\
\text { vivos e não-vivos. }\end{array}$ & $\begin{array}{l}1 \text { dia de aula para elaboração de hipóteses e } \\
\text { montagem dos experimentos ("plantar" pedras } \\
\text { em um vasinho e feijão em outro. O que aconte- } \\
\text { ce?). Observação, cuidados com os dois vasinhos } \\
\text { (água e luz) e anotações ao longo dos dias. Refor- } \\
\text { mulação de hipóteses, conclusões e explicações. }\end{array}$ \\
\hline$P$ & $\begin{array}{lr}\text { "Por que } & \text { con- } \\
\text { servamos } & \text { os } \\
\text { alimentos } & \text { na } \\
\text { geladeira?" } & \end{array}$ & $\begin{array}{l}\text { Curiosidade apre- } \\
\text { sentada pelo filho } \\
\text { da estudante. }\end{array}$ & $\begin{array}{l}\text { Micro-organismos } \\
\text { (decomposição) e } \\
\text { compostagem. }\end{array}$ & $\begin{array}{l}1 \text { dia de aula para início da elaboração de hipó- } \\
\text { teses e montagem do experimento (conservar } \\
\text { uma maçã na geladeira e a outra não). Uso de } \\
\text { um "diário do cientista" para anotações do que } \\
\text { vai ocorrendo ao longo dos dias (em torno de } \\
14 \text { dias de observação). } 1 \text { dia para construção } \\
\text { de uma composteira e para trabalhar a impor- } \\
\text { tância da compostagem. }\end{array}$ \\
\hline $\mathrm{R}$ & $\begin{array}{l}\text { "Como nascem } \\
\text { e crescem as } \\
\text { plantas?" }\end{array}$ & $\begin{array}{l}\text { Curiosidade apre- } \\
\text { sentada por uma } \\
\text { criança conhecida } \\
\text { da estudante. }\end{array}$ & $\begin{array}{l}\text { Sementes, ne- } \\
\text { cessidades das } \\
\text { plantas (água, } \\
\text { luz), compreensão } \\
\text { inicial da fotossín- } \\
\text { tese. }\end{array}$ & $\begin{array}{l}1 \text { dia de aula para experimentação: plantar dife- } \\
\text { rentes sementes em diferentes ambientes (por } \\
\text { exemplo: com luz, sem luz, colocar água em } \\
\text { algumas outras não). Emissão de hipóteses pe- } \\
\text { las crianças. Observação e anotações ao longo } \\
\text { dos dias. } 2 \text { dias para organização dos resulta- } \\
\text { dos, construção de texto e desenho, comunica- } \\
\text { ção dos resultados aos colegas. }\end{array}$ \\
\hline
\end{tabular}

Fonte: As autoras (2017). 


\section{As "vozes" das crianças}

Planejar a partir dos questionamentos infantis exigiu uma escuta à curiosidade da criança e uma elaboração didático-pedagógica inédita a partir de cada um deles. $\mathrm{O}$ ensino do ciclo da água pode representar a resposta para o questionamento "A água que cai da chuva é a mesma que bebemos?", mas a forma como essa "resposta" foi planejada configurou-se como uma decisão-construção da futura professora, assim como a decisão de valorizar a pergunta da criança. Banegas (2014) questiona a TD descrita por Chevallard quando ela exclui da noosfera e da TD Interna os estudantes e, também, quando considera o professor apenas como reprodutor de currículos previamente estabelecidos.

Alguns autores destacam a importância da educação científica desde os primeiros anos da escolaridade e os ganhos cognitivos e sociais advindos dessas atividades. Reiteram, ainda, as crianças como participantes ativos, com interesse real em Ciência (DUSCHL; SCHWEINGRUBER; SHOUSE, 2007; HARLEN, 2010). Para elaborar e proferir um questionamento do tipo "Se gelo também é de água como ele boia na água?" a criança demonstra ter observado o fenômeno físico, suas propriedades e comportamento.

A escuta e a valorização dessas perguntas podem encorajar e estimular as crianças a continuarem perguntando, em qualquer tempo, durante as aulas de Ciências. Baram-Tsabari et al. (2006) defendem a utilização das perguntas das crianças sobre Ciência como uma estratégia poderosa de motivação e de mapeamento de interesses científicos delas. Para os autores, as perguntas infantis podem funcionar, inclusive, como norteadoras do currículo em sala de aula e de reformas curriculares em nível de políticas públicas. Para tanto, de acordo com Cremin et al. (2015), as estratégias didático-metodológicas em Ciências precisam permitir que a criança acredite em seu potencial criativo, além de envolver seu senso de novas possibilidades, dando a ela a confiança necessária para questionar e experimentar.

Mesmo a estudante AC formulando a pergunta que deu origem ao seu planejamento (“O que aconteceria se as abelhas desaparecessem?”), essa poderia corresponder a um questionamento de uma criança. Propor questões desafiadoras iniciais aos alunos também se configura como estratégia de desencadeamento da curiosidade, estimulando-os a criarem hipóteses, pensarem em possíveis desdobramentos, além de continuarem o processo de elaboração de mais perguntas. 
Sabe-se que nem toda pergunta proferida pelos alunos exige elaborações de planejamentos mais extensos, assim como não é possível construir aulas sobre cada um, entre uma infinidade possível, dos questionamentos infantis. Essa escolha é uma atribuição docente, a partir de uma análise ampla do currículo, do contexto escolar, de seus objetivos e de suas concepções pedagógicas.

Temos clareza de que a formação inicial não dá conta da complexidade da sala de aula, dos ritmos de aprendizagem dos alunos, das influências externas e internas que a escola sofre e das diversidades e especificidades da educação brasileira. Durante a formação inicial, estabelece-se um cenário estável e "ideal" pouco provável de ser reproduzido em sua totalidade. O processo de formação na universidade representa um primeiro passo, o qual, de acordo com Veiga (2008), nunca terá fim. Para a autora, o processo de formação é multifacetado e a atividade docente requer uma constante formação, com conhecimentos adequados para o exercício profissional que possam ser utilizados na melhoria da ação docente.Por isso a necessidade da formação inicial basear-se no exercício da criatividade, da inovação e da pesquisa por parte dos estudantes de Pedagogia, a começar pela escuta da curiosidade e dos questionamentos infantis.

\section{respaldo das políticas públicas}

Que lugar ocupa a autonomia docente diante da necessidade em se seguir uma política curricular normativa? Apesar das recomendações e normatizações, acreditamos que há (e precisa haver) no currículo espaço para as "vozes" dos diferentes agentes envolvidos no processo educacional, principalmente, em nível escolar e de sala de aula. Cândido e Gentilini (2017) defendem que o documento final da BNCC não deve ser a única referência para as escolas, sendo necessário, tanto em sua construção como em sua implementação, ouvir o que professores, estudantes e comunidade, pensam desse processo. Para os autores, torna-se absolutamente necessário pensar num Projeto Pedagógico que possa dialogar com a Base e suas possíveis inovações, garantindo o direito e a valorização da intervenção de todos nessa construção que fundamenta a educação nacional.

Dessa forma, mesmo as estudantes tendo trabalhado tópicos presentes na BNCC, obtendo, portanto, o respaldo da política pública vigente, partiram de questões, anseios e dúvidas infantis. Ainda, cada pergunta que deu origem aos planejamen- 
tos passou por uma avaliação e seleção prévia realizada por elas quando optaram por uma entre tantas outras perguntas possíveis. Assim, foi pessoal a escolha pela condução dos planejamentos com determinados tipos de atividades. Segundo Lôbo (2012), o professor tende a priorizar o desenvolvimento de conteúdos e estratégias propostas nos currículos oficiais que estão de acordo com seu sistema de crenças, valores, concepções e habilidades profissionais.

Para Lopes et al. (2010) a autonomia do professor no Ensino de Ciências é transferida para a prática mediante pequenos gestos, como: a) atribuição do tempo necessário para execução das ações educativas; b) auxílio ao aluno quando esse atinge o ponto de bloqueio, com questionamentos e incentivo à formulação de hipóteses; c) promoção dos momentos de diálogos e partilha de ideias entre os estudantes; e d) escuta atenciosa aos questionamentos, dúvidas e argumentações dos discentes.

\section{A formação inicial}

Em relação ao processo de formação inicial, as necessidades formativas se apresentam como fatores que podem exercer impacto direto na configuração do perfil do futuro profissional, que, ao carregar consigo insuficiências formativas, poderá se tornar multiplicador de uma Educação Científica errônea, fundamentada em visões simplistas da Ciência e na falta de conhecimentos didáticos e pedagógicos para o exercício da docência (DE CARVALHO; FELICIANO; LUCAS, 2018), justificando, assim, a importância dessa categoria de análise. Nela, reunimos os dados dos planejamentos que, após análise, demonstraram ser resultantes da formação inicial vivenciada pelas estudantes, seja na disciplina ministrada por nós, seja em outros espaços-tempos formativos. Dividimos essas construções formativas em subcategorias, considerando as reflexões didáticas descritas por Astolfi e Develay (2001), a saber: reflexão epistemológica, reflexão pedagógica e reflexão psicológica.

Reflexão epistemológica das Ciências na formação inicial

Compreender epistemologicamente uma área subjaz o entendimento de seus princípios lógicos e investigativos (LIBÂNEO, 2012a). Por esse motivo, investimos na abordagem epistemológica da Ciência durante a disciplina ofertada às estudantes de Pedagogia, mesclando explicações teóricas com práticas que, implicitamente, contivessem tais conceitos transpostos às Ciências da Natureza. 
Assim, buscamos identificar nos planejamentos a compreensão e a possível incorporação desses aspectos na TD realizada pelas estudantes para o universo infantil. Lorenzetti e Delizoicov (2001) destacam a importância de se trabalhar com as crianças habilidades referentes aos processos pelos quais se constrói o conhecimento científico, aguçando a criatividade, a curiosidade, o questionamento constante, a observação, a investigação, as emissões de hipóteses e a resolução de problemas, com o objetivo de alfabetizar cientificamente as crianças.

Merece destaque, portanto, o estímulo à elaboração de hipóteses identificado em, pelo menos, seis planejamentos, demonstrando a preocupação das futuras professoras em elaborarem atividades que forneçam tempo de fala às crianças, que permitam o diálogo e que as levem a criar e a pensar para além de passos pré-estabelecidos. A valorização do papel da hipótese na construção do conhecimento científico aponta para uma perspectiva epistemológica racionalista contemporânea e sua elaboração caracteriza-se como um processo complexo, com origem na imaginação fértil, inspiradora, envolto de um fundo reflexivo (PRAIA; CACHAPUZ; GIL-PÉREZ, 2002). Para os autores, uma vez formulada a hipótese, torna-se necessário, em seguida, sua confirmação e duas vias são possíveis no processo: a confirmação positiva e a negativa. $O$ processo de confirmação positiva nada nos diz sobre a verdade da hipótese já que esta pode ser falsa, mas confirmada, necessitando uma sistemática confirmação positiva para ajudar a tornar o trabalho científico mais apoiado (PRAIA; CACHAPUZ; GIL-PÉREZ, 2002).

A aluna AC, ao propor uma temática de interesse social, econômico e ambiental (“O que aconteceria se as abelhas desaparecessem?"), vinculou a criação de hipóteses à indissociabilidade das relações entre Ciência, Tecnologia e Sociedade (CTS) e a uma infinidade de cenários possíveis, tendo em vista o imaginativo pensamento infantil. De acordo com Sasseron e Carvalho (2008), o entendimento das relações existentes entre ciência, tecnologia, sociedade e meio-ambiente representa um dos eixos estruturantes do processo de Alfabetização Científica e perpassa pelo reconhecimento de que quase todo fato da vida de alguém tem sido influenciado, de alguma maneira, pelas ciências e tecnologias. Assim, para as autoras, mostra-se fundamental de ser trabalhado quando temos em mente o desejo de um futuro saudável e sustentável para a sociedade e o planeta.

Após uma possível "chuva de ideias" lançada pelas crianças, caberá à professora conduzir a pesquisa e a investigação das hipóteses levantadas, situação que impli- 
ca preparação e pesquisa da docente. De acordo com Praia, Cachapuz e Gil-Pérez (2002), trata-se de uma perspectiva que exige dos alunos grande capacidade criativa, assim como um bom fundo teórico e espírito crítico, cabendo ao docente incitar a diferença e o pensamento divergente, para levar a descobrir o que não é esperado. Para se mobilizar tais competências, capacidades e atitudes, torna-se necessário conhecer bem o contexto em que se opera e, neste sentido, o domínio dos conteúdos científicos é um requisito para que tal possa acontecer (PRAIA; CACHAPUZ; GIL-PÉREZ, 2002).

As estudantes A, I, L, P e R propuseram que, a partir das hipóteses levantadas, as crianças passassem a elaborar experimentos para testá-las, criando diferentes desenhos experimentais para a condução das investigações. A estudante A propôs que as crianças pesquisassem, com a utilização de computador e internet, explicações para suas hipóteses que pudessem confirmá-las ou falseá-las. Em outro momento, sugeriu a construção pelas crianças de um sistema “caseiro" para filtragem da água da chuva, com a utilização de garrafa pet, pedras, areia, carvão e algodão (Figura 1).

Figura 1: Esquema de um filtro "caseiro" proposto pela estudante A.

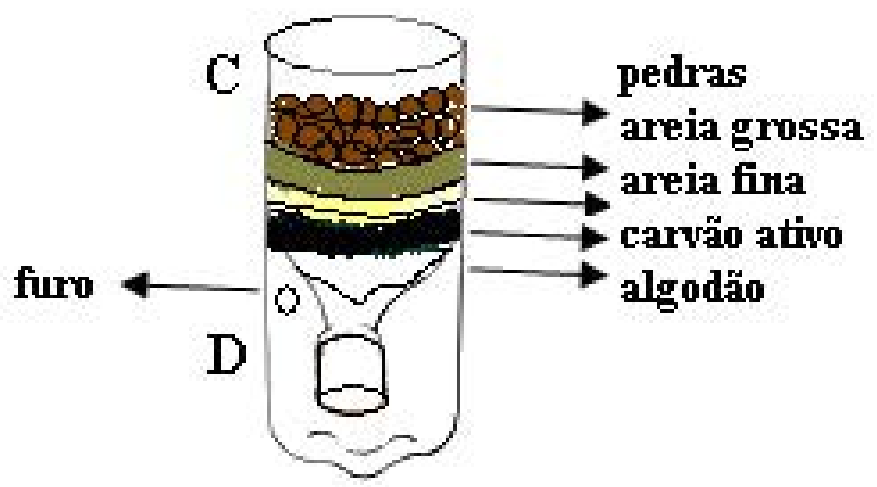

Fonte: Arquivo pessoal da estudante A (2017).

A partir disso, o planejamento previu a observação em microscópio óptico de águas coletadas em diferentes ambientes antes e após a filtragem e a solicitação de desenho e anotações a serem realizados pelas crianças. A observação e o registro, entre outras, são habilidades e procedimentos da investigação científica que podem ser concebidos como um conjunto de habilidades presentes nas investigações das mais variadas áreas da Ciência (PADILLA, 1990). Jiménez-Aleixandre et al. (2008) 
descrevem o aprendizado em Ciências em termos de práticas epistêmicas, as quais não envolvem apenas conceitos científicos, mas a forma como esses conceitos são construídos e empregados. Para os autores, a descrição e o uso de desenhos resultantes de observações de seres vivos e estruturas biológicas, por exemplo, envolvem práticas epistêmicas com a utilização de conceitos para interpretar dados e a articulação do conhecimento observacional e conceitual.

A estudante I escolheu um questionamento envolvendo conceitos físicos e registrou a seguinte justificativa em seu trabalho escrito:

Escolhi esse tema por ser uma matéria que eu tinha mais dificuldade. Na escola eu gostava muito de ciências, mas quando era biologia, nunca tive muita afinidade com física e química, sempre achei difícil, chato e não conseguia ver como aplicar os conhecimentos na prática, então resolvi escolher um tema de física para tentar torná-lo mais interessante e atrativo. A ideia veio através do meu irmão que me pediu para estudar esse tema com ele para uma prova e tinha esse questionamento em mente (estudante I).

Rosa, Perez e Drum (2007) discorrem acerca da tendência dos professores dos anos iniciais em abordarem mais conteúdos ligados à Biologia em detrimento da Física, as quais, mesmo compondo as Ciências da Natureza, possuem epistemologias diferenciadas. O ideal é que a abordagem se desenvolva de forma interdisciplinar, envolvendo a contribuição das áreas, incluindo ainda a Química, na resolução dos problemas apresentados. De toda forma, a compreensão conceitual torna-se necessária, tal como destacou a estudante I ao buscar estudar parte da Física que pra ela era encarada como "chata e difícil".

A estudante conduziu seu trabalho prevendo possíveis hipóteses das crianças para o questionamento inicial (“Se gelo também é de água como ele boia na água?”), realizando e fotografando quatro experimentos para testá-las. O primeiro experimento encontra-se descrito no trecho a seguir:

[...] podemos incentivar as crianças a pensarem em motivos para isso. Uma possibilidade de resposta das crianças poderia ser: porque ele foi colocado por cima, ou porque foi colocado por último. Então podemos perguntar para se elas acham que se colocássemos mais água por cima da água o gelo também boiaria. Provavelmente as crianças que deram esse motivo iriam responder que sim. Então podemos testar essas possibilidades. $1^{\text {a }}$ experiência:pedir que as crianças peguem um pouco de água, misturem com corante e coloquem em um recipiente já com água. Elas irão perceber que a água com corante não vai ficar por cima da outra água e sim vai se misturar com ela. Agora para testar com o gelo elas podem tentar colocá-lo de outras formas na água, por exemplo, colocar primeiro o gelo no copo depois adicionar água (estudante I) (Figura 2). 
Figura 2: Experimento utilizando água, corante e gelo realizado pela estudante I.
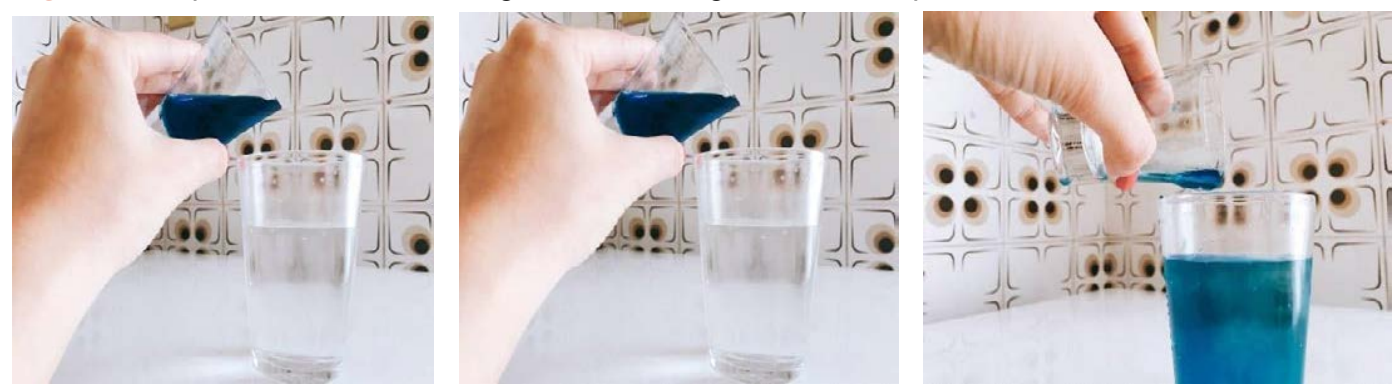

Fonte: Arquivo pessoal da estudante I (2017).

Destacamos positivamente a tentativa da estudante em "prever" as hipóteses infantis e desenvolver experimentos para testá-las. Praia, Gil-Pérez e Vilches (2007), no entanto, chamam atenção para as exigências suplementares de rigor quando se trabalha em termos de hipóteses, sendo necessário duvidar sistematicamente dos resultados obtidos e de todo o processo seguido para os obter. Para os autores, portanto, é necessário atenção para as interpretações simplistas dos resultados das experiências e para um possível "reducionismo experimentalista".

A estudante I incluiu, ainda, História da Ciência em seu planejamento, através da história de Arquimedes e da coroa do rei Hieron. A tentativa de utilização da história da Ciência, aspecto abordado durante a disciplina, foi reconhecida e destacada durante a apresentação da estudante. A seleção dessa história, no entanto, foi, em partes, questionada pela docente/pesquisadora em aula, uma vez que apresenta ressalvas históricas, conceituais e epistemológicas. De acordo com Martins (2000), essa história contribui para uma visão errônea da Ciência, ou seja, de que ela evolui por acidentes. Além disso, para o autor, faz um serviço negativo ao próprio ensino da Física, pois descreve um método inviável de comparação de densidades, em vez de ensinar como se poderia realmente detectar a fraude da coroa do rei. "Infelizmente, a lenda da água transbordando na banheira continua até hoje a ser repetida e contada nas escolas e nas universidades e provavelmente continuará a ser contada no futuro" (MARTINS, 2000, p.121).

A estudante R, a partir do questionamento "Como nascem e crescem as plantas?" previu a realização de experimentos diversos pelas crianças utilizando diferentes sementes. Assim, pensou em plantar sementes em um vasinho que receberia somente água, em outro que teria apenas terra, alguns seriam colocados em local 
com incidência de luz solar, outros em locais escuros e assim por diante, conforme as combinações imaginadas pelas crianças. A estudante sugeriu a utilização de um "diário do cientista" no qual as crianças fariam observações ao longo dos dias com suas impressões e explicações a partir da observação do desenvolvimento (ou ausência dele) das plantas. Quando houvesse a germinação e o crescimento da planta de um dos vasinhos, as crianças seriam estimuladas a explicarem quais os elementos que permitiram o desenvolvimento da planta e por quê. Assim, ela entraria com o conteúdo relacionado à germinação de sementes e à fotossíntese.

De acordo com Lima e Maués (2006), a investigação no ensino de Ciências para os anos iniciais trata-se de uma atitude e de um modo de arguir o mundo, sendo próprio da Ciência e dos cientistas, aproximando as pessoas de outro modo de pensar e de explicar para além das crenças e dogmas (LIMA; MAUÉS, 2006), ou seja, do senso comum (BACHELARD, 2005). Por esse motivo a necessidade das professoras dos anos iniciais introduzirem atividades investigativas no plano social da sala de aula, reconhecendo a importância do desenvolvimento de procedimentos relacionados à inventividade científica, à emissão de hipóteses e a interpretação dos resultados, à argumentação lógico-abstrata e à comunicação de ideias, bem como de se fortalecer as atitudes de dúvida, tolerância, colaboração e comunicação das ideias entre as crianças (LIMA; MAUÉS, 2006), fundando aspectos de alfabetização científica (SASSERON; CARVALHO, 2008).

Nesse sentido, a estudante C (“Alguns alimentos podem fazer mal à saúde?”), entre outras atividades, sugeriu que as crianças pesquisassem junto aos familiares os hábitos alimentares, interpretando os dados de acordo com os componentes nutricionais dos alimentos consumidos. A partir disso, as crianças seriam instigadas a criar formas de representar graficamente os componentes mais consumidos, justificando se os hábitos seriam ou não saudáveis, propondo algumas intervenções nos cardápios da família com base na teoria aprendida em sala de aula. O planejamento explorou a pesquisa, a compilação de dados e a construção de gráficos com análise estatística, a interpretação, a comunicação dos resultados e a elaboração de propostas de intervenção junto à comunidade participante da pesquisa. Observar, classificar, diferenciar, testar, significar, descrever, concluir, teorizar, questionar, comparar, julgar, decidir, levantar hipóteses, discutir, planejar são ações que aproximam o fazer científico da sala de aula (LIMA; MAUÉS, 2006). Para Harlen (2002), a educação científica não é completa quando as aulas de ciências só enfatizam o 
conteúdo e deixam de fornecer subsídios para que os alunos sejam capazes de raciocinar cientificamente, usando as habilidades e os procedimentos da investigação científica. Tal aprendizagem poderá também auxiliar os alunos na compreensão e melhor entendimento de como os cientistas obtêm os conhecimentos sobre o mundo ao seu redor (HANUSCIN; ROGERS, 2008).

Epistemologicamente as estudantes realizaram Transposições Didáticas valorizando o trabalho coletivo, a discussão entre os pares, a observação, o desenho e a anotação, a pesquisa, a análise de dados, a interpretação e comunicação dos dados, todas essas características do fazer científico e que cabem ao desenvolvimento e à curiosidade infantil. Essas ações encontram consonância na epistemologia de Bachelard a partir de sua defesa a uma pedagogia científica (FONSECA, 2008) e à construção de um espírito científico (BACHELARD, 2005) que rompa com o conhecimento usual. Fonseca (2008) explica que, no pensamento de Bachelard, a pedagogia científica se materializa quando o professor rompe com os paradigmas cartesianos-lógicos-racionais e fundamenta sua prática na resolução de questões, no questionamento, na ruptura. O espírito que não é desafiado começa a preferir respostas às perguntas, pois tendemos a nos acostumar com aquilo que confirma nosso saber (BACHELARD, 2001 apud FONSECA, 2008). É do entendimento de Bachelard que o dogmatismo desconstrói toda a criatividade, sendo necessário ao professor ser muito menos alguém que ensina e mais alguém que desperta, estimula, provoca, questiona e se deixa questionar (FONSECA, 2008).

\section{Reflexão Pedagógica}

Pedagogicamente, destacamos a diversidade metodológica selecionada pelas estudantes em seus planejamentos às crianças, como: aula de campo, material lúdico e literatura infantil (estudante CJ), abordagem CTS, teatro e filme infantil (estudante AC), visita técnica e aula de laboratório (estudante A), construção de aparatos pelas crianças como filtro de água (estudante A) e composteira (estudante P), utilização do computador e internet (estudante A), elaboração e utilização de mapa conceitual (estudante $\mathrm{P}$ ), análise e interpretação de rótulos de alimentos (estudante C), experimentações diversas (demais estudantes).

A estudante CJ (“Como nascem as borboletas?") planejou uma atividade de campo na qual as crianças teriam que realizar uma "caça ao tesouro" ao ar livre na 
procura por peças de quebra-cabeça que, ao serem encaixadas, formariam a imagem do ciclo de vida da borboleta. CJ justificou sua escolha pelo quebra-cabeça porque não encontrou um casulo e uma borboleta reais. Em sua ideia inicial, ela coletaria uma borboleta morta e um casulo, enquanto a lagarta seria representada por uma imagem ou por um modelo didático para não oferecer risco de queimadura. Assim, as crianças teriam que procurar as peças do quebra-cabeça, explicando e tentando completar o ciclo de vida da borboleta. As duas alternativas são igualmente aplicáveis no contexto escolar e a escolha da estudante representa o que, muitas vezes, passa o professor na tentativa de encontrar materiais biológicos para as aulas de Ciências. A substituição por um quebra-cabeça demonstrou a capacidade de improvisação da futura docente sem que fosse necessário cancelar a atividade de campo ou, no caso da disciplina, sem atrapalhar a apresentação do trabalho.

Por permitirem o contato direto com o ambiente, as aulas de campo possibilitam que o estudante se envolva e interaja em situações reais de aprendizagem (VIVEIRO; DINIZ, 2009). Diversos autores concordam que essas iniciativas podem estimular o processo de ensino e de aprendizagem (KRASILCHIK, 2004; FERNANDES, 2007; MARANDINO; SELLES; FERREIRA, 2009), oportunizando a descoberta de novos ambientes, incluindo a observação e o registro de imagens (MORAIS; PAIVA, 2009) e a promoção do espírito científico dos alunos por meio do desenvolvimento da capacidade de observação (NUNES; DOURADO, 2009). Ainda, instigam a curiosidade e aguçam os sentidos, tornando possível confrontar teoria e prática, oferecendo a oportunidade de se trabalhar de forma coletiva e interdisciplinar (MARANDINO; SELLES; FERREIRA, 2009).

A estudante CJ ainda fez uso da literatura infantil para contar a história de uma borboleta (Figura 3) e construiu uma "televisão interativa" que podia ser manipulada pelas crianças ao rodarem as imagens para "mudar de canal" (Figura 4). De acordo com Linsingen (2008), as obras infantis podem conversar mais com o literário ou com o pedagógico, mas sempre apresentam potencial de complemento, ponto de partida ou problematização. Brayner (2005) destaca a importância da formação de professores para que abordem a literatura infantil, retirando um caráter instrumental e ressignificando a ludicidade e o encantamento do discurso pedagógico em sala de aula. 
Figura 3: Trecho da história infantil sobre o ciclo de vida da borboleta escolhida pela estudante CJ.
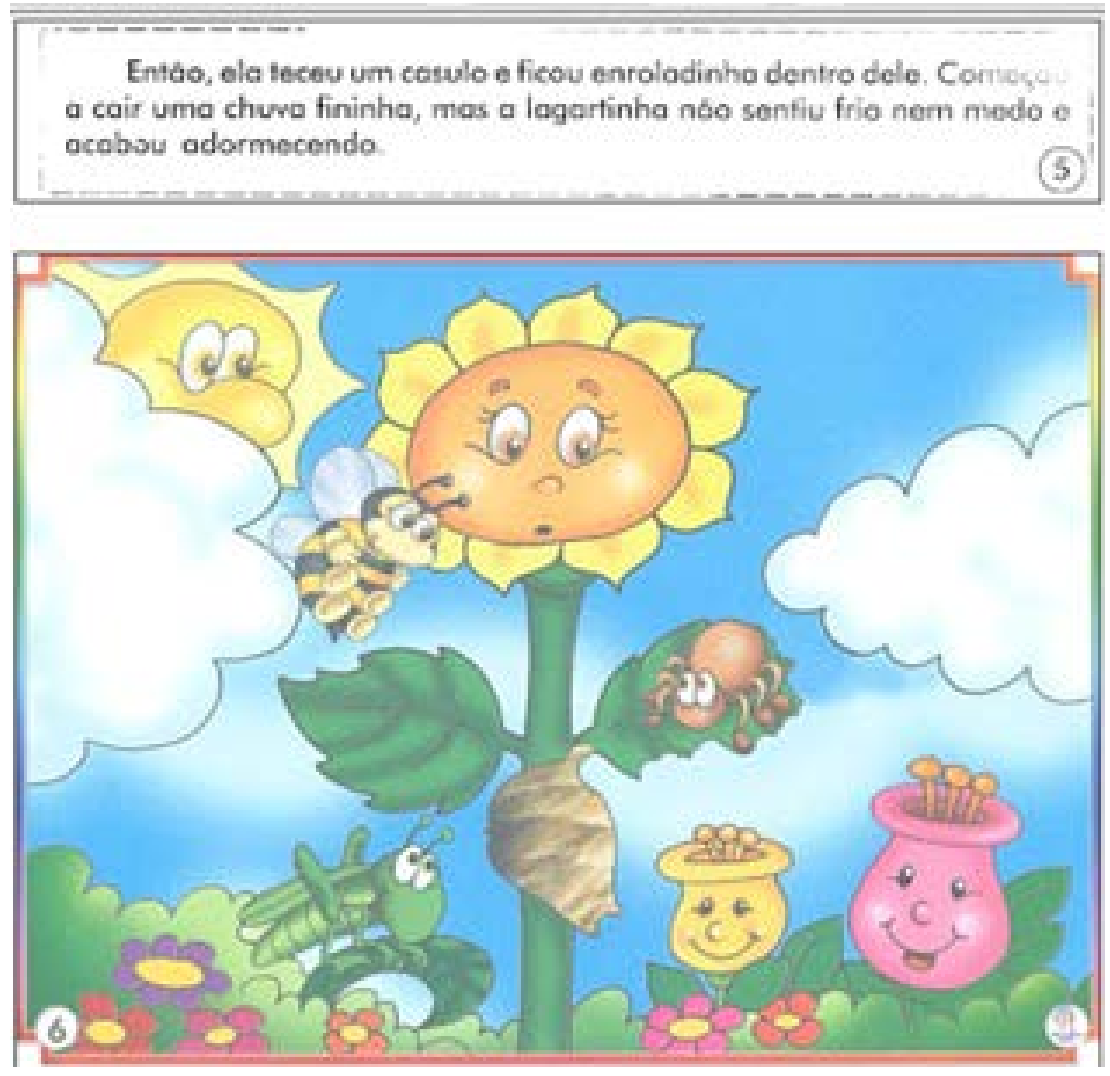

Fonte: Arquivo pessoal da estudante CJ (2017).

Chama atenção na história (texto e imagem), questão dialogada após a apresentação da estudante, a atribuição de características humanas (antropomorfismo) aos seres vivos presentes na história, bem como alguns erros conceituais como a quantidade de patas da aranha e do gafanhoto ilustrados. A antropomorfização é um recurso bastante utilizado na literatura infantil para que animais, e outros seres vivos retratados, possam atuar na história e ganhar empatia do leitor, agregando valor estético e lúdico (HUNT, 2010). A prática pode acarretar, no entanto, na sedimentação dos conceitos apresentados de forma equivocada (HUNT, 2010), principalmente, quando esses são representados com erros conceituais além da antropomorfização. Para Pinto e Raboni (2005), autores de ficção infantil não precisam ter o rigor da linguagem e da representação científica em suas obras, o que poderia até distanciá-las do público-alvo. Os autores alertam, no entanto, para a construção 
de sentidos quanto aos conceitos biológicos presentes e, também, quanto ao papel do docente na mediação e na problematização das incongruências encontradas nas histórias.

Figura 4: Algumas imagens apresentadas na "televisão" construída pela estudante CJ.
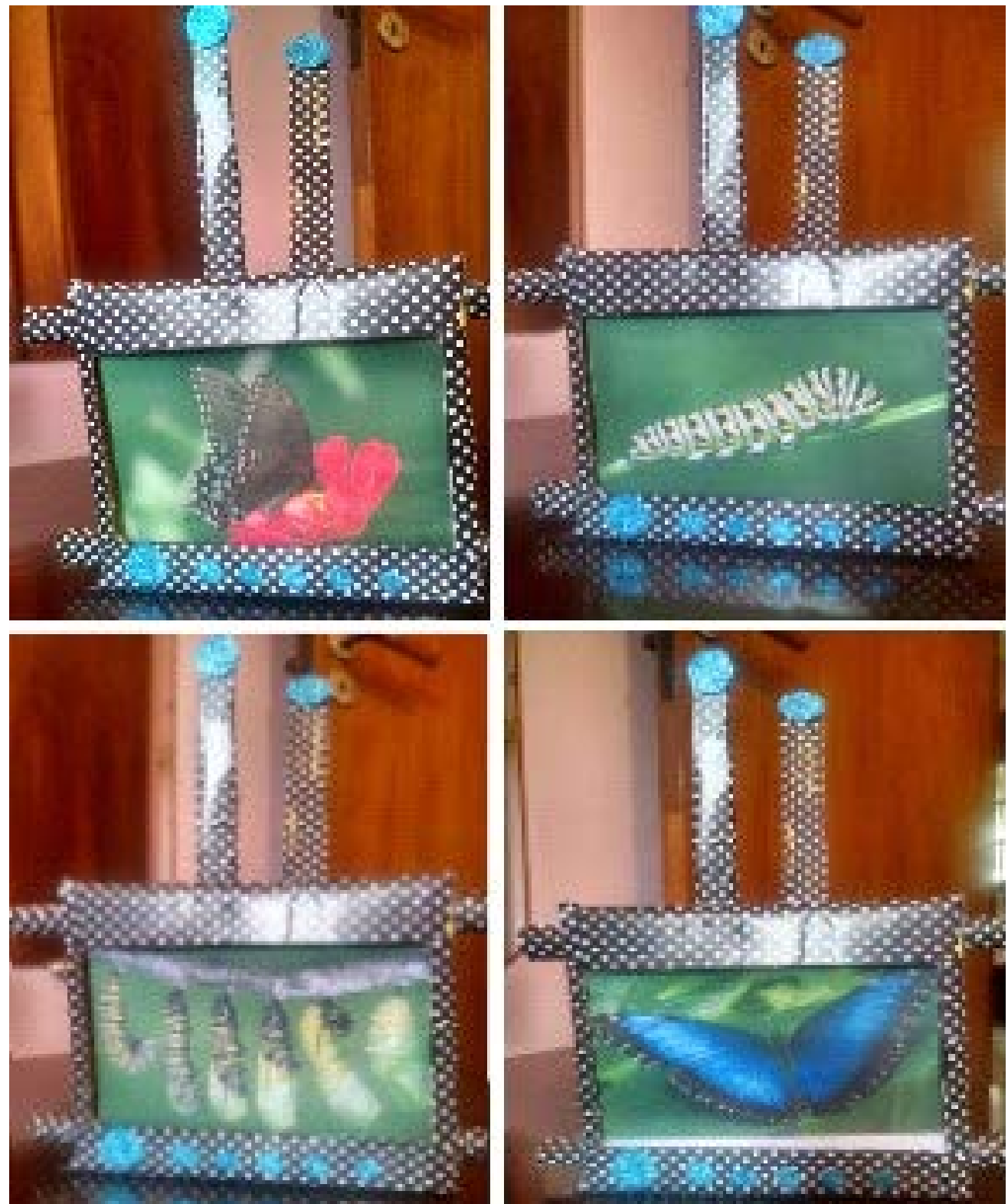

Fonte: Arquivo pessoal da estudante CJ (2017). 
Destacamos, ainda, a escolha pedagógica da estudante AC ("O que aconteceria se abelhas desaparecessem?”) pelo teatro no qual algumas crianças representariam as abelhas polinizando, com a utilização de velcro e bolinhas de feltro (pólen), enquanto outras crianças interpretariam as flores. A partir das hipóteses levantadas, discutidas e pesquisadas, as crianças representariam as causas apontadas para a diminuição das abelhas, como agrotóxicos, desmatamento, queimadas, mudanças climáticas, entre outros, interpretando também as consequências da diminuição ou desaparecimento delas. Segundo Pretto e Vestena (2012), o teatro, seja no ambiente acadêmico ou escolar, compõem um viés para o desenvolvimento de habilidades de criação, desinibição, comunicação e expressão. Tomando como base a concepção da criança como ser integral, constata-se que as atividades que ela realiza na escola, muitas vezes, têm um tratamento compartimentado: uma hora é determinada para trabalhar a coordenação motora, outra para trabalhar expressão plástica, outra para brincar sob a orientação do professor, outra para brincadeira não-direcionada e assim por diante (FREDMANN, 2006). Essa divisão não favorece a formação da personalidade integral das crianças nem de suas necessidades, enquanto o teatro pode representar a conjunção desses elementos (FREDMANN, 2006).

A estudante A (“A água que cai da chuva é a mesma que bebemos?") optou por desenvolver uma aula de laboratório em uma das etapas do planejamento, com utilização de microscópio, estimulação à observação e ao desenho por parte das crianças. Já destacamos na seção anterior alguns aspectos epistemológicos de atividades desenvolvidas no laboratório, a partir da observação e do registro. São as características pedagógicas associadas a essas práticas, no entanto, que transpõem didaticamente a Ciência à escola de modo a se configurar de fato como um conhecimento escolar. Segundo as Diretrizes Curriculares Nacionais, é importante que as atividades experimentais sejam planejadas para incluir os estudantes em momentos de construção de conceitos e em situações em que possam desenvolver habilidades cognitivas superiores, apresentando uma função pedagógica que as diferencie das experiências que os cientistas conduzem nos seus laboratórios (BRASIL, 2013).

Como já mencionado no artigo, as práticas pedagógicas docentes são orientadas pelas concepções epistemológicas e, sendo assim, distanciar-se de concepções empírico-indutivistas da Ciência aproxima o trabalho pedagógico às novas ideias, à criatividade e ao diálogo. Para Lôbo (2012),o laboratório precisa se converter em um ambiente de aprendizagem no qual o estudante possa interagir com os conhe- 
cimentos teóricos/conceituais, assim como com os conhecimentos metodológicos/ práticos, dependendo do enfoque didático da aula.

A estudante $\mathrm{P}$ ("Por que conservamos os alimentos na geladeira?")elaborou um experimento que ela realizou e testou em casa. O experimento da estudante consistiu em observar o que acontece ao longo do tempo com duas maçãs: uma conservada na geladeira e outra no ambiente por 14 dias. O tempo foi definido e julgado como suficiente por ela após a realização da experiência em casa (Figura 5).

Figura 5: Experiência realizada pela estudante $P$ na qual uma maçã foi conservada na geladeira e outra fora durante 14 dias.

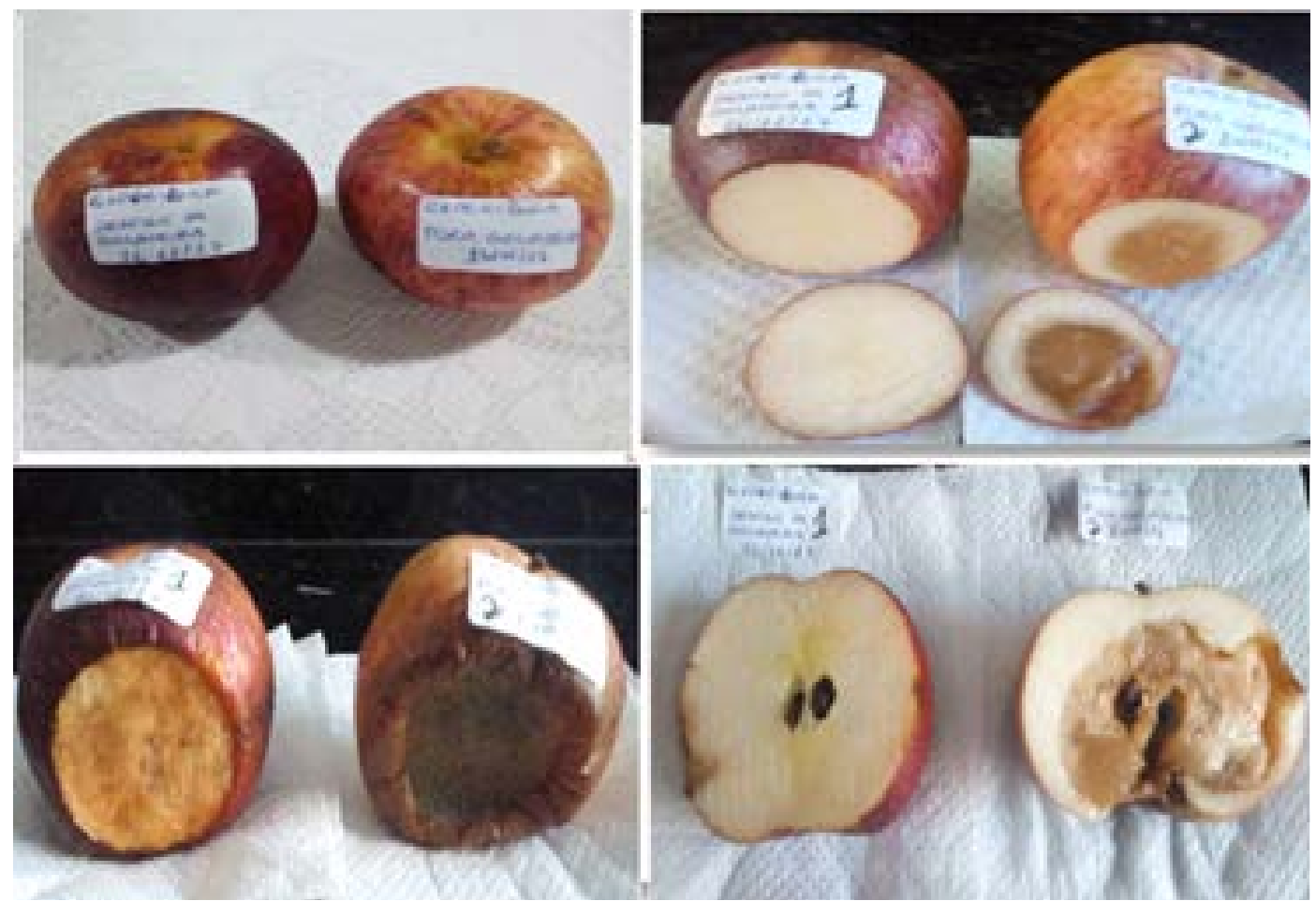

Fonte: Arquivo pessoal da estudante P (2017).

Segundo a estudante, a experiência foi criada para instigar as crianças a pensarem na importância do ciclo da matéria orgânica, culminando na proposta de construção de uma composteira. A construção de composteiras foi assunto citado em uma das aulas ao longo da disciplina por uma aluna, gerando interesse nas demais colegas. Na ocasião, poucas conheciam e sabiam como construir. Assim, a estudante 
$\mathrm{P}$ buscou esse conhecimento autonomamente, inserindo em seu planejamento de forma integrada com os demais conceitos trabalhados. Santos et al. (2014) apresenta diversas possibilidades pedagógicas e conteúdos curriculares das Ciências que podem ser trabalhadas a partir da compostagem, como lixo, produção de energia, misturas e soluções, poluição do solo, modelos de agricultura, reciclagem de nutrientes, ciclos biogeoquímicos, entre outros.

Ainda, ao longo da disciplina, foi utilizado um mapa conceitual para exemplificar algumas conexões possíveis a partir da temática da fotossíntese. A estudante $\mathrm{P}$ arriscou-se a criar seu próprio mapa conceitual, demonstrando as ligações entre os conceitos do planejamento proposto por ela. Previu também a construção de mapas conceituais pelas crianças ao longo da experimentação para que pudessem compreender as conexões semânticas entre os conceitos. Mapas conceituais representam um recurso embasado pela Teoria da Aprendizagem Significativa de Ausubel, com colaboração de autores como Novak e Gowin, entre outros (MENDONÇA; MOREIRA, 2012). De acordo com Moreira (2006), os mapas conceituais são diagramas que indicam relações entre conceitos, ou entre palavras usadas para representar conceitos, podendo ser considerados como um estruturador do conhecimento, na medida em que permitem mostrar como o conhecimento sobre determinado assunto está organizado na estrutura cognitiva de seu autor, que assim pode visualizar e analisar sua profundidade e extensão. Além disso, podem ser entendidos como uma representação visual utilizada para partilhar significados, pois explicam como o autor do mapa entende as relações e as hierarquizações entre os conceitos listados (MOREIRA, 2006). Há nos mapas três elementos fundamentais:

\begin{abstract}
conceitos, que se referem a regularidades em eventos ou objetos, caracterizados por atributos criteriais e que podem ser identificados por substantivos e adjetivos (ex.: folhas amarelas); proposições, constituídas por dois ou mais termos conceituais unidos por palavras de ligação para formar uma unidade semântica, correspondem a frases com significados determinados (ex.: no outono muitas folhas ficam amarelas); palavras ou verbos de ligação que unem os conceitos para formar as proposições que indicam o tipo de relação existente entre eles (ex.: e, então, contém, tipo de, exemplo de, leva a, implica, entre outros) (MENDONÇA; MOREIRA, 2012, p.13)
\end{abstract}

Dessa forma, o mapa da estudante $\mathrm{P}$, apesar de possuir um questionamento e um desenho inseridos, apresenta semelhanças com essa estrutura, interligando conceitos conforme a própria estudante os compreendeu e organizou seu planejamento (Figura 6). 
Figura 6: Mapa conceitual construído pela estudante P.

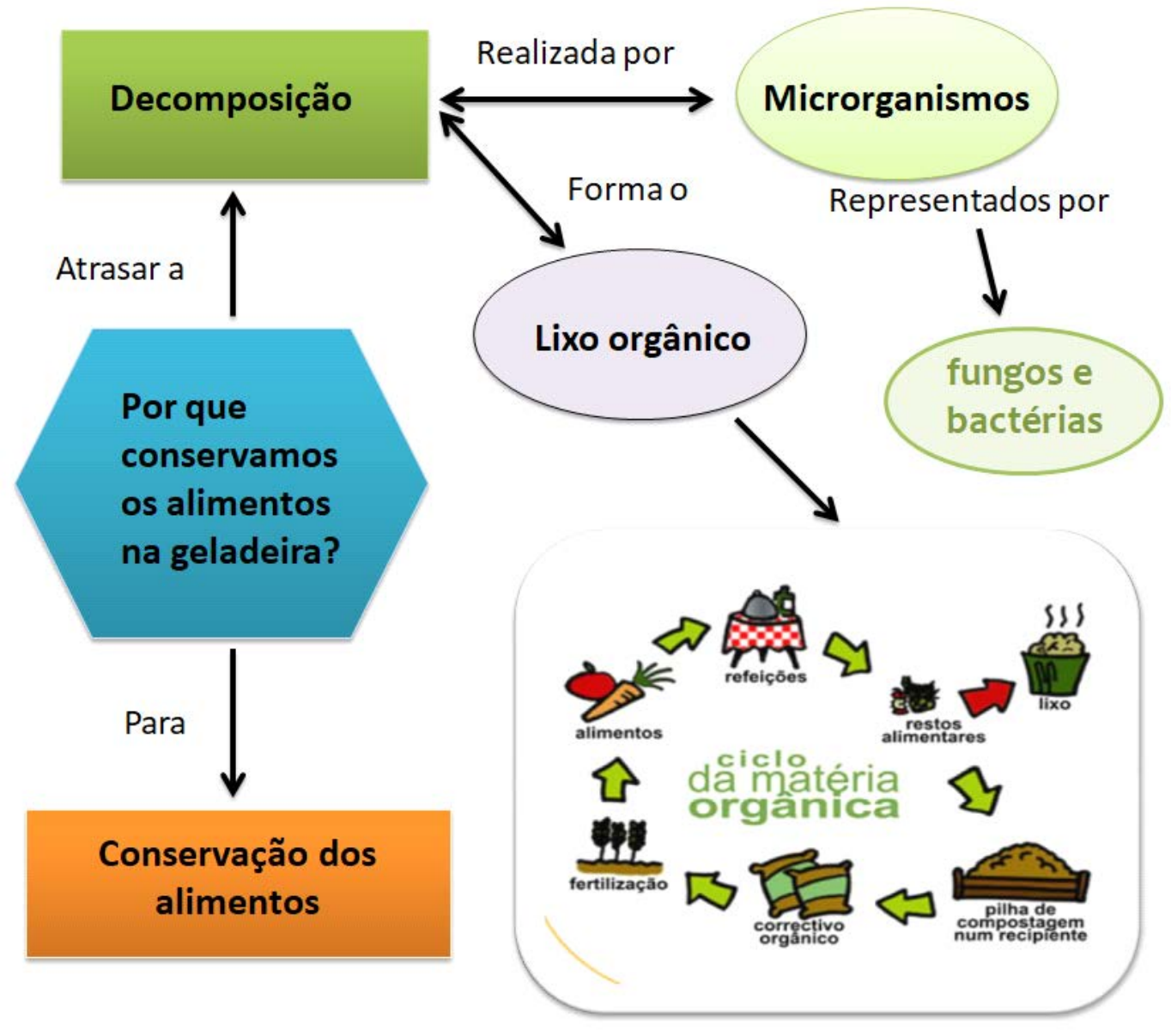

Fonte: Arquivo pessoal da estudante P (2017).

De modo geral, pedagogicamente, as estudantes utilizaram diferentes estratégias e recursos abordados ao longo da disciplina, demonstrando as construções realizadas a partir da formação inicial. Destacamos o fato de não terem reproduzido como cópia as estratégias trabalhadas em aula, mas inserido novas elaborações conectadas de maneira coerente com o tópico escolhido. A diversidade metodológica presente nos planejamentos, bem como a qualidade teórica da elaboração, ressalvando algumas questões que foram novamente dialogadas no dia da apresentação e destacadas nesta pesquisa, estão de acordo com a literatura na área do Ensino de Ciências. Como exemplo, apresentamos o que Megid-Neto e Fracalanza (2003) apontam como habilidades 
pedagógicas necessárias aos professores dos anos iniciais, as quais foram, em partes, contempladas pelas estudantes em seus planejamentos: a) capacidade de seleção e confecção de materiais para utilização nas aulas de Ciências; b) capacidade de realização de atividades experimentais, pois são importantes para familiarizar as crianças com os processos de construção do conhecimento científico, gerando motivação; c) introdução de atividades lúdicas; d) preparação de aulas que agreguem teoria e prática; e) habilidade para utilizar ambientes naturais no desenvolvimento dos conteúdos, visto que as aulas de Ciências podem ser bastante proveitosas quando realizadas nesses locais; f) saber analisar criticamente e escolher os materiais didáticos, haja vista que muitos livros e outros materiais de Ciências para os anos iniciais apresentam erros na apresentação dos conteúdos, além de visões distorcidas acerca da Natureza da Ciência.

\section{Reflexão Psicológica}

As reflexões inseridas nesta seção contemplam tanto os aspectos cognitivos quanto os afetivos/motivacionais. Seniciato, Pinheiro da Silva e Cavassan (2006) discorrem que, muitas vezes, as práticas educativas restringem-se ao domínio cognitivo sem preverem estratégias que contemplem a construção de valores e sublinhem essa formação mais afetiva nos alunos. Historicamente, as dimensões cognitivas e afetivas tenderam a ser tratadas de forma separada, contemporaneamente, entretanto, percebe-se uma tendência de reunião delas, numa tentativa de recomposição do ser humano completo (RUIZ; OLIVEIRA, 2005). A educação tradicional e os currículos escolares, ao trabalharem de maneira puramente cognitiva a Matemática, as Linguagens, as Ciências, entre outros, acabam por priorizar apenas um desses aspectos constituintes do psiquismo humano, em detrimento do outro (SENICIATO; PINHEIRO DA SILVA; CAVASSAN, 2006).

Destacamos as características lúdicas inseridas pelas estudantes em seus planejamentos, como o teatro proposto pela estudante $\mathrm{AC} \mathrm{("O} \mathrm{que} \mathrm{aconteceria} \mathrm{se} \mathrm{abelhas}$ desaparecessem?”), o qual acaba por explorar o estético a partir dos figurinos e cenário e a criatividade das crianças na condução da história. Para Pretto e Vestena (2012), o teatro pelo seu perfil lúdico e envolvente, pode se constituir em um caminho capaz de sensibilizar os estudantes, a dinamizar novas ideias, a fortalecer valores pessoais e sociais, potencializar talentos, a acessar novos saberes e conhecimentos científicos.

A aula de campo planejada pela estudante CJ também oferece oportunidades para além do cognitivo. De acordo com Compiani (2012), no ensino de Ciências, 
tanto os laboratórios quanto as salas de aula, muitas vezes, apresentam-se como um mundo fechado em si mesmo, primando por um modo de representação altamente abstrato e generalista. Em contraposição, no campo:

a natureza é toda iluminada, arejada e permeável aos diferentes sentidos; no rural, o silêncio, pássaros e borboletas, flores e cheiros; nas cidades, o barulho do trânsito, cheiros dos postos de gasolina, luzes e neon, que 'perturbariam' a concentração intelectual, mas, na verdade, se incorporam num conjunto de percepções e pensamentos para a aprendizagem. Essas materialidades e não materialidades entram em conflito com o pensamento por meio de uma fricção que geram faíscas cognitivas, iluminando a própria vida-mundo do leitor do lugar-ambiente (COMPIANI, 2012, p. 150).

O mapa conceitual utilizado pela estudante $\mathrm{P}$ é um instrumento que pode ser usado pelo professor e pelo aluno. Quando elaborado pelos alunos, atende ao desenvolvimento de habilidades e não se conforma somente com a repetição mecânica da informação, o que possibilita desenvolver as dimensões de uma pessoa no lado afetivo e no intelectual (MOREIRA, 2006). Assim, para o autor, o mapa conceitual é percebido como estratégia de ensino e de aprendizagem com importantes repercussões no âmbito afetivo-relacional da pessoa, uma vez que o papel a ser desempenhado pelo aluno, a atenção, a aceitação e o aumento de seu êxito na aprendizagem favorece, paralelamente, o desenvolvimento de sua autoestima.

A escolha por trabalhar com experimentação/investigação com criação de hipóteses pela maioria das estudantes também favorece aspectos psicológicos. Cremin et al. (2015) destacam a existência potencial de uma série de sinergias pedagógicas entre a ciência baseada na investigação e abordagens baseadas na criatividade na educação dos primeiros anos, incluindo: brincadeiras e exploração, motivação e afeto, diálogo e colaboração, resolução de problemas e agenciamento, questionamento e curiosidade, reflexão e raciocínio.

Psicologicamente, por fim, destacamos a construção de materiais lúdicos pelas estudantes, caráter que alimenta a motivação das crianças para entender seu mundo, despertando o fascínio, a admiração e o interesse que podem estimular o engajamento estético, incentivar a curiosidade e levar ao uso da investigação científica para desenvolver explicações dos fenômenos (CREMIN et al., 2015). Lemke (2006) demonstra preocupação em tornar o ensino de Ciências mais prazeroso e adequado às habilidades e anseios de cada faixa etária. Para o autor, com as crianças não se pode abandonar o mistério, a curiosidade e o surpreendente, apreciando e valorizando o mundo natural. 


\section{Concepções pessoais}

Não conseguimos identificar diretamente aspectos pessoais de crenças e valores nas transposições, mas concordamos que esses estão imbricados nas demais categorias. Acreditamos que as questões infantis que motivaram o desenvolvimento dos planejamentos, os caminhos didáticos-metodológicos selecionados em cada planejamento, bem como a influência da formação inicial que se fez relevante para cada estudante e que se mostrou nas reflexões pedagógicas, epistemológicas e psicológicas da TD sofrem influência das concepções pessoais delas.

Em contexto escolar, outras variáveis ainda se farão presentes na influência à TD, como a realidade de cada escola, o projeto pedagógico, as diferentes conformações sociais da comunidade escolar, entre outros fatores. De acordo com Oliveira (2001), os valores e crenças dos profissionais pedagogos são afetados pela formação inicial na construção das representações, mas não de forma dominante. Participam desse processo todas as demais situações e experiências vividas pessoal e profissionalmente.

A Figura 7 apresenta um esquema geral de nossos achados neste trabalho a partir da análise dos planejamentos das estudantes de Pedagogia.

Figura 7: Esquema representando o processo de Transposição Didática realizado pelas estudantes de Pedagogia na elaboração dos planejamentos.

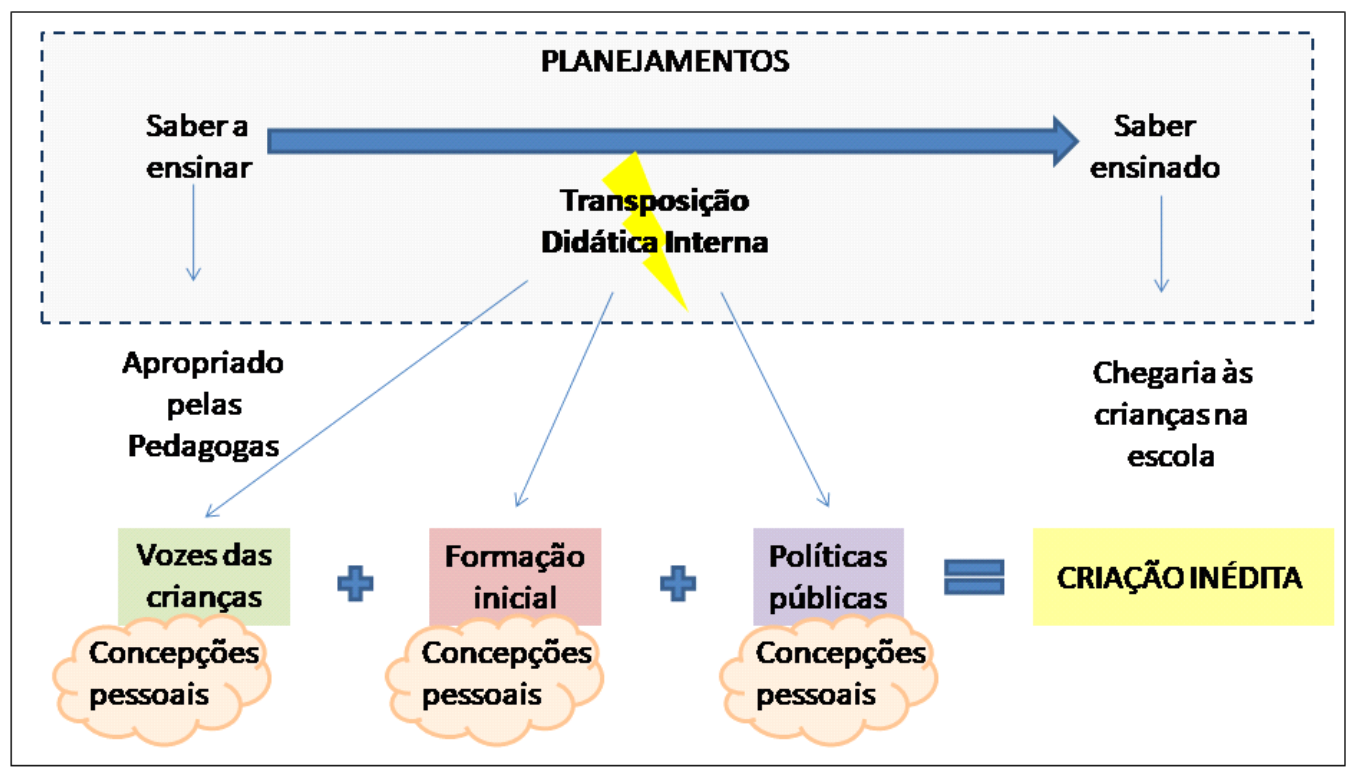

Fonte: As autoras (2017). 


\section{Considerações finais}

A partir de planejamentos construídos por estudantes de Pedagogia ao final de uma disciplina voltada à Alfabetização Científica no Ensino de Ciências para crianças, objetivamos investigar quais influências se mostraram e como se mostraram no processo de Transposição Didática realizado por elas. Para tanto, elegemos quatro elementos organizativos da análise: a influência das crianças ao perguntarem, das políticas públicas, da formação inicial vivenciada na disciplina e no Curso como um todo e das concepções pessoais das estudantes.

Os dados fundamentaram o processo de TD como um produto inédito para cada futura docente, dependente da formação inicial, inspirado pelas políticas públicas e pelas crianças, mas com diferentes conduções metodológicas a partir de escolhas individuais de cada uma. Planejar com base em questionamentos infantis foi encarado como um desafio, todas as estudantes, no entanto, conseguiram conduzir seus planejamentos explorando aspectos epistemológicos, pedagógicos e psicológicos das Ciências de modo a valorizar as características infantis aliadas ao fazer científico.

As estudantes exploraram variados aspectos epistemológicos demonstrando compreensão da Ciência em uma perspectiva racionalista-contemporânea. Inseriram o estímulo à elaboração de hipóteses, à pesquisa, à experimentação, ao registro, à interpretação dos resultados, à argumentação lógico-abstrata, à comunicação de ideias. Tais tópicos conduziram suas opções pedagógicas e psicológicas por caminhos de diálogo, ludicidade, colaboração, tolerância, criatividade, possibilidade de elevação da autoestima das crianças ao valorizarem suas perguntas e explicações. Acreditamos que a compreensão epistemológica auxilia na clarificação pedagógica e psicológica. A valorização da criança e de suas particularidades infantis, no entanto, entendemos também ser reflexo da formação inicial ao longo de todo o Curso de Pedagogia, demonstrando a capacidade das estudantes na integração dos conhecimentos docentes para que, de fato, materializem-se em ações em sala de aula.

Identificamos alguns equívocos teóricos e inadequações epistemológicas, os quais foram dialogados com as estudantes ainda na apresentação. Elas mostraram-se abertas às adequações e correções necessárias, compreendendo teoricamente $o$ porquê da necessidade de reformulação.

Tendo em vista as contundentes críticas na literatura à formação de Pedagogos para a atuação em disciplinas específicas e a complexidade do currículo do Curso de 
Pedagogia, concluímos como profícuas nossas iniciativas na disciplina voltadas ao Ensino de Ciências na perspectiva da AC. Temos consciência do inacabamento da formação docente, mas nossos resultados reiteram o quanto um processo formativo inicial pode suscitar fagulhas de (trans)formação nos sujeitos que os compartilham, reforçando a responsabilidade dos Cursos de Pedagogia em oferecerem oportunidades de formação que valorize ideias, estimulando a criação e a autonomia em Ciências.

\section{Science to children: Didactical Transposition in initial training of educators as creative (trans)formation process}

\section{Abstract}

Based on children's natural curiosity to make questions, testing and create, it is necessary that Nature Science teaching in first years of school valorizes and stimulates those characteristics, in a way that allies aspects of Science by itself and its development. Then, it is necessary to invest in initial training of educators on focused on it. From a Science Teaching course, offered to Pedagogy students of a Public University of the central region in Rio Grande do Sul, Brazil, we propose to analyze the production of initial years activities plannings to Nature Sciences, made by students in the end of the course. We aimed to investigate how knowledge Didactical Transposition (DT) process was made. To do that, we elect four organizative analysis elements, based on Content Analysis, considering the influence of: children when asking, public policy, initial training, and student's personal conceptions. Data analysis shows DT as a new product to each future-teacher. Students elaborate their plannings exploring epistemological, pedagogical and psychological aspects of Science, puting value on child characteristics allied to the scientific making. Our results reaffirm how much a initial formative processes can rise up (trans)formation in subjects who share them, which reinforce the responsibility of Pedagogy Undergraduate Courses in offering opportunities in formation, which valorizes ideas and stimulates the creation and autonomy in Science.

Keywords: Initial training, Pedagogy, Elementary School, Science Education, Didactical Transposition

\section{Referências}

ASTOLFI, J. P.; DEVELAY, M. A didática das ciências. Campinas, SP: Papirus Editora, $6^{\mathrm{a}}$ Ed., 2001.

BACHELARD, G. A formação do espírito científico: contribuição para uma psicanálise do conhecimento. Trad: ABREU, E. dos S. 5 $5^{\mathrm{a}}$ reimpressão. Rio de Janeiro: Contraponto, 2005.

BANEGAS, D. L. Democratizingdidactictransposition: Negotiationsbetweenlearnersandtheirteacher in a secondaryschool. Latin American JournalofContentandLanguageIntegrated Learning, v. 7, n.2, p.1-26, 2014.

BARAM-TSABARI , A.; SETHI , R. J.; BRY , L.; YARDEN, A. UsingQuestionsSentto na Ask-A-Scientist Site toIdentifyChildren'sInterests in Science. Science Education, v. 90, n. 6, p. 1050-1072, 2006. 
BARDIN, L. Análise de Conteúdo. Edição revista e ampliada. Pt: Edições 70 Brasil, 2011.

BOSCH, M.; GASCÓN, J. Twenty-fiveyearsofthedidactictransposition. ICMI Bulletin, 58, 5165. 2006.

BRANDI, A.; GURGEL, C. A Alfabetização Científica e o processo de ler e escrever em séries iniciais: emergências de um estudo de investigação. Ciência \& Educação, v. 8, n.1, p. 113-12, 2002.

BRASIL. Ministério de Educação. Diretrizes Curriculares Nacionais para o Curso de Graduação em Pedagogia, licenciatura. Resolução CNE/CP 1/2006. Diário Oficial da União, Brasília, 16 de maio de 2006, Seção 1, p. 11, 2006.

BRASIL. Ministério da Educação. Base Nacional Comum Curricular. Brasília, 2017

Diretrizes curriculares nacionais gerais da educação básica. Brasília: MEC, 2013.

BRAYNER, F. H. A. Como salvar a educação (e o sujeito) pela literatura: sobre Philippe Meirieu e Jorge Larrosa. Revista Brasileira de Educação, Rio de Janeiro: n. 29, 63-72, 2005.

CACHAPUZ, A.; GIL-PEREZ, D.; CARVALHO, A. M. P. de; PRAIA, J.; VILCHES, A. A necessária renovação do ensino das ciências. São Paulo: Editora Cortez, 2005.

CÂNDIDO, R. de K.; GENTILINI, J. A. Base curricular nacional: reflexões sobre autonomia escolar e o projeto político-pedagógico. Revista Brasileira de Política e Administração Escolar, v. 33, n. 2, 2017.

CAVALCANTE, R. B.; CALIXTO, P.; PINHEIRO, M. K. Análise de conteúdo: considerações gerais, relações com a pergunta de pesquisa, possibilidades e limitações do método. Inf. \&Soc.:Est., João Pessoa, v.24, n.1, p. 13-18, 2014.

CHEVALLARD, Y. La TranspositionDidactique: Du SavoirSavantauSavoirEnsigné. Grenoble, La penséeSauvage, 1991.

CREMIN, T.; GLAUERT, E.; CRAFT, A.; COMPTON, A.; STYLIANIDOU, F. Creative Little Scientists: exploringpedagogicalsynergiesbetweeninquiry-basedandcreative approaches in EarlyYearsscience. InternationJournalofPrimary, ElementaryandEarlyYearsEducation, v. 43, n.4, 2015.

COMPIANI, M. O Desprestígio das Imagens no Ensino de Ciências, Até Quando? Uma contribuição das Geociências com a Gestalt. Alexandria, v. 5, n. 1, p. 127-154, 2012.

DE SOUZA CARVALHO, C.; FELICIANO, F.; BUENO LUCAS, L. Abordagens Metodológicas De Ensino Na Formação Inicial De Professores De Ciências E Biologia: Um Curso Formativo Sobre O Enfoque Histórico-Filosófico Da Ciência. RBECM, 1, 155-173, 2018.

DELIZOICOV, D.; ANGOTTI, J. A.; PERNAMBUCO, M.M. Ensino de Ciências: fundamentos e métodos. São Paulo: Cortez, 2002.

DELIZOICOV, N. C.; SLONGO, I. I. P. O ensino de Ciências nos anos iniciais do Ensino fundamental: elementos para uma reflexão sobre a prática pedagógica. Série-Estudos - Periódico do Programa de Pós-Graduação em Educação da UCDB, Campo Grande, MS, n. 32, p. 205-221, 2011.

DUSCHL, R. A.; SCHWEINGRUBER, H. A.; SHOUSE, A. W. Taking Science toSchool. Washington, DC:NationalAcademy Press, 2007.

FERNANDES, J. A. B. Você vê essa adaptação? A aula de campo em ciências entre o retórico e o empírico. São Paulo, 2007. 326p. Tese (Doutorado em Educação) - Faculdade de Educação, Universidade de São Paulo, São Paulo, 2007. 
FONSECA, D. M. da. A pedagogia científica de Bachelard: uma reflexão a favor da qualidade da prática e da pesquisa docente. Educação e Pesquisa, v.34, n.2, p. 361-370, 2008.

FRIEDMANN, A. O desenvolvimento da criança através do brincar. São Paulo: Moderna, 2006.

GATTI, B. A.; BARReTto, E. S. de S. Professores do Brasil: impasses e desafios. Brasília: Unesco, 2009.

GATTI, B. A.; NUNES, M. M. R. (orgs.). Formação de Professores para o Ensino Fundamental: Estudo de Currículos das Licenciaturas em Pedagogia, Língua Portuguesa, Matemática e Ciências Biológicas. Coleção Textos FCC, vol. 29, 2009.

GODOY, A. S. Pesquisa qualitativa: tipos fundamentais. Revista de Administração de empresas. São Paulo, v. 35, n. 3, 1995.

HANUSCIN, D. L.; ROGERS, M. A. P. Learning to observe and infer. Science and Children, Arlington, v. 45, n. 6, p. 56-57, 2008.

HARLEN, W. Teaching, learningandassessingscience 5-12. London: Paul Chapman, 2002.

,W. Principlesand big ideasofscienceeducation. Association for Science Education, 2010.

HUNT, P. Crítica, teoria e literatura infantil. São Paulo: Cosac Naify, 2010.

JIMÉNEZ-ALEIXANDRE, M. P.; MORTIMER, E. F.; SILVA, A. C. T.; DÍAZ, J. EpistemicPractices: ananalytical framework for scienceclassrooms. Paperpresentedto AERA, New York City, 2008.

KRASILCHIK, M. Prática de ensino de biologia. 4 ed. São Paulo: EDUSP, 2004.

LEMKE, J, L. Investigar para el futuro de laeducación científica: nuevas formas de aprender, nuevas formas de vivir. Enseñanza de lãs Ciencias, v. 24, n 1., p. 5-12, 2006.

LIBÂNEO, J. C. O ensino da Didática, das metodologias específicas e dos conteúdos específicos do ensino fundamental nos currículos dos cursos de Pedagogia. R. bras. Est. pedag., Brasília, v. 91 , n. 229 , p. $562-583,2010$.

. Ensinar e aprender, aprender e ensinar: o lugar da teoria e da prática em didática. Temas de pedagogia: diálogos entre didática e currículo. São Paulo: Cortez Editora, 2012a.

A persistente dissociação entre o conhecimento pedagógico e o conhecimento disciplinar na formação de professores: problemas e perspectivas. Anais. 35ª Reunião Anual da Anped, 2012b.

LIMA, M. E. C. DE C.; MAUÉS, E. Uma releitura do papel da professora das séries iniciais no desenvolvimento e aprendizagem de ciências das crianças. Ensaio, v. 8, n. 2, 2006.

LINSINGEN, L. V. Alguns motivos para trazer literatura infantil para as aulas de Ciências. Ciência \& Ensino, v. 2, n. 2, 2008.

LÔBO, S. F. O trabalho experimental no ensino de química. Química Nova, São Paulo, v. 35, n.2, p. 430-434, 2012.

LOPES, A. C. L.; MACEDO, E. Teorias de currículo. São Paulo: Cortez, 280 p., 2011.

LOPES, J. B.; SILVA, A. A.; CRAVINO, J. P.; VIEGAS, C.; CUNHA, A. E.; SARAIVA, E.; BRANCO, M. J.; PINTO, A. SILVA, A.; SANTOS, C. A.. Investigação sobre a mediação de professores de ciências físicas em sala de aula. Vila Real: Universidade de Trás-os-Montes e Alto Douro, 2010.

LORENZETTI, L.; DELIZOICOV, D. Alfabetização científica no contexto das séries iniciais. Revista Ensaio, v. 3, n. 1, 2001. 
MALAFAIA, G.; RODRIGUES, A. S. de L. Uma reflexão sobre o ensino de ciências no nível fundamental da educação. Ciência \& Ensino, vol. 2, n. 2, 2008.

MALDANER, O. A.; ZANON, L. B.; AUTH, M. A. Pesquisa sobre educação em ciências e formação de professores. IN. SANTOS, F. M. T.; GRECA, I. M. A pesquisa em Ensino de Ciências no Brasil e suas metodologias. Ijuí: Unijuí, p.49-88, 2006.

MARAFELLI, C. M.; RODRIGUES, P. A. M.; BRANDÃO, Z.A formação profissional dos professores: um velho problema sob outro ângulo. Cad. Pesqui. [online]. v.47, n.165, pp.982-997, 2017.

MARANDINO, M.; SELLES, S.E.; FERREIRA, M.S. Ensino de Biologia histórias e práticas em diferentes espaços educativos. São Paulo: Cortez, 2009.

MARTINS, R. de A. Arquimedes e a coroa do rei: problemas históricos. Cad.Cat.Ens.Fís.,v.17, n.2 p.115-121, 2000.

MEGID-NETO, J.; FRACALANZA, H. O livro didático de ciências: problemas e soluções. Ciência e Educação, v. 9, n. 2, p. 147- 157, 2003.

MENDONÇA, C. A. S.; MOREIRA, M. A. Uma revisão da literatura sobre trabalhos com mapas conceituais no ensino de ciência do pré-escolar às séries iniciais do ensino fundamental. Revista Práxis, v. 4, n. 7, 2012.

MORAIS, M. B.; PAIVA, M. H. Ciências: ensinar e aprender. B. Horizonte: Dimensão, 2009.

MOREIRA, M. A. Mapas conceituais e diagramas V, Ed. do autor, Porto Alegre, 2006.

NUNES, I. E.; DOURADO, L. Concepções e práticas de professores de Biologia e Geologia relativas à implementação de ações de Educação Ambiental com recurso ao trabalho laboratorial e de campo. Revista Electrónica de Enseñanza de lasCiencias, v. 8, n. 2, p. 671-691, 2009.

OLIVEIRA, D.C., Análise de Conteúdo Temático Categorial: Uma proposta de sistematização. Rev. Enferm. UERJ, Rio de Janeiro, v.16, n.4, p. 569-76, 2008.

OLIVEIRA, M. M. Como fazer pesquisa qualitativa. Petrópolis, Vozes, 2007.

OLIVEIRA, S. M. L. Crenças e valores dos profissionais de creche e a importância da formação continuada na construção de um novo papel junto a crianças de 0 a 3 anos. Em Aberto, v. 18, n. 73, p. 89-97, 2001.

OVIGLI, D. F. B.; BERTUCCI, M. C. S. A formação para o ensino de ciências naturais nos currículos de pedagogia das instituições públicas de ensino superior paulistas. Ciências \& Cognição, v. 14 , n. 2, p. 194-209, 2009.

PADILLA, M. J. The scienceprocess skills. ResearchMatters - tothe Science Teacher, Reston, n. 9004, 1990.

PIMENTA, S. G.; FUSARI, J. C.; PEDROSO, C. C. A.; PINTO, U. de A. Os cursos de licenciatura em pedagogia: fragilidades na formação inicial do professor polivalente. Educ. Pesqui., São Paulo, v. 43, n. 1, p.15-30, 2017.

PINTO, A. A.; RABONI, P. C. A. Concepções de ciência na literatura infantil brasileira: conhecer para explorar possibilidades. In: NARDI, Roberto; BORGES, Oto. Atas do V ENPEC. Bauru, SP, n. 5, 2005. 
PIRES, E. A. C.; SAUCEDO, K. R. R.; MALACARNE, V. Concepções sobre a natureza da Ciência de alunos concluintes do curso de Pedagogia. Revista Electrónica de Enseñanza de las Ciencias, v. 16, n. 2, p. 215-230, 2017.

PIZARRO, M. V.; BARROS, R. C. dos S. N.; LOPES JUNIOR, J. Os professores dos anos iniciais e o ensino de Ciências: uma relação de empenho e desafios no contexto da implantação de Expectativas de Aprendizagem para Ciências. RBPEC. v. 16. n. 2. pp. 421-448, 2016.

PRAIA, J.; CACHAPUZ, A.; GIL-PÉREZ, D. Problema, teoria e observação em ciência:para uma reorientação epistemológica da Educação em Ciência. Ciência \& Educação, Bauru, v. 8, n. 1, p. 127-145, 2002.

PRAIA, J.; GIL-PÉREZ, D.; VILCHES, A. O papel da natureza da ciência na educação para a cidadania. Ciência \& Educação, Bauru, v. 13, n. 2, p. 141-156, 2007.

PRETTO, V.; VESTENA, R. de F. O teatro no ensino de Ciências: uma alternativa metodológica para os anos iniciais. Vidya, v.32, n.2, p.9-20, 2012.

ROSA, C. W.; PEREZ, C. A. S.;DRUM, C. Ensino de física nas séries iniciais: concepções da prática docente. Investigações em Ensino de Ciências, v. 12, n. 3, p.357-368, 2007.

RUIZ, V. M.; OLIVEIRA, M. J. V. de. A dimensão afetiva da ação pedagógica. Educ@ação: Rev. Ped. - Unipinhal-SP, v. 01, n. 03, 2005.

SANTOS, A. M. de L. dos.; MARTINS, R. M. de L.; SOUZA, R. D. de.; MOTA, R. M. F.; FERNANDES, C. T. F. Incentivo ao Uso da Compostagem de Resíduos Sólidos em uma Horta Escolar do Município de Jaciara-MT. UNOPAR Cient., Ciênc. Human. Educ., Londrina, v. 15, n.esp, p. 321-329, 2014.

SANTOS, A. R. dos. Os saberes necessários à prática pedagógica do professor de Ciências do contexto amazônico. X Simpósio Linguagens e Identidades da/na Amazônia Sul - Ocidental. Anais, n, 1, 2016.

SASSERON, L. H.; CARVALHO, A. M. P. Almejando alfabetização científica no ensino fundamental: a proposição e a procura de indicadores do processo. Investigação em Ensino de Ciências, Porto Alegre: UFRGS, v. 13, n. 3, p. 333-352, 2008.

. Alfabetização científica: uma revisão bibliográfica. Investigações em Ensino de Ciências, Porto Alegre: UFRGS, v. 16, n. 1, p. 59-77, 2011.

SENICIATO, T.; PINHEIRO DA SILVA, P. G.; CAVASSAN, O. Construindo valores estéticos nas aulas de ciências desenvolvidas em ambientes naturais. Rev. Ensaio, Belo Horizonte, v.08, n.02, p.119-131, 2006.

VEIGA, I. P. A. Organização didática da aula: um projeto colaborativo de ação imediata. In.: VEIGA, Ilma Passos Alencastro (org.). Aula: gênese, dimensões, princípios e práticas. Campinas, SP: Papirus, p. 267-298, 2008.

VIVEIRO, A. A.; DINIZ, R. E. S. Atividades de campo no ensino das Ciências e na educação ambiental: refletindo sobre as potencialidades desta estratégia na prática escolar. Ciência em Tela, v. 2, n. 1, p. 1-12, 2009.

ZABALZA, M. O ensino universitário: seu cenário e seus protagonistas. Porto Alegre: Artmed, 2004. 